REVIEW Article

\title{
Critical physiological and pathological functions of Forkhead Box $O$ tumor suppressors
}

\author{
Georgiana R. Dumitrascu ${ }^{1}$ and Octavian Bucur ${ }^{2, *}$
}

1"Victor Babes" National Institute of Pathology and Biomedical Sciences, Bucharest, Romania; ${ }^{2}$ Department of Pathology, Harvard Medical School and Beth Israel Deaconess Medical Center, Boston, MA, USA;

Correspondence to: Dr. Octavian Bucur, Department of Pathology, Harvard Medical School and Beth Israel Deaconess Medical Center, 330 Brookline Ave, Boston, MA, 02215, USA. Phone: +1 617667 4314; E-mail: obucur@bidmc.harvard.edu.

Citation: Dumitrascu GR, Bucur O. Critical physiological and pathological functions of Forkhead Box O tumor suppressors. Discoveries 2013, Oct-Dec; 1(1): e5. DOI: 10.15190/d.2013.5

\begin{abstract}
The Forkhead box, subclass O (FOXO) proteins are critical transcription factors, ubiquitously expressed in the human body. These proteins are characterized by a remarkable functional diversity, being involved in cell cycle arrest, apoptosis, oxidative detoxification, DNA damage repair, stem cell maintenance, cell differentiation, cell metabolism, angiogenesis, cardiac development, aging and others. In addition, FOXO have critical implications in both normal and cancer stem cell biology. New strategies to modulate FOXO expression and activity may now be developed since the discovery of novel FOXO regulators and non-coding RNAs (such as microRNAs) targeting FOXO transcription factors. This review focuses on physiological and pathological functions of FOXO proteins and on their action as fine regulators of cell fate and context-dependent cell decisions. A better understanding of the structure and critical functions of FOXO transcription factors and tumor suppressors may contribute to the development of novel therapies for cancer and other diseases.
\end{abstract}

Keywords: FOXO, FOX, apoptosis, cancer, stem cells, cancer stem cells, microRNAs

\section{Abbreviations}

B-cell lymphoma 2 (Bcl-2); bcl-2 interacting mediator of cell death (Bim); p53 upregulated modulator of cell death (Puma); Bcl-2/adenovirus E1B 19 kDa-interacting protein (bNIP3); PTEN - induced kinase 1 (Pink1); peroxisome proliferative activated receptor-gama (PGC1); glucose-6-phosphatase (G6Pase); phosphorenol-pyruvate carboxykinase (PEPCK); Agouti-related protein (Agrp); neuropeptide Y (NpY); pro-opiomelanocortin (POMC); glycogenolytic gene glucose-6phosphatase (G6pc); manganese superoxide dismutase (MnSOD); CBP/p300-interacting trans-activator with ED-rich tail 2 (Cited 2); mixed lineage leukemia (MLL); L-selectin (CD62L); activation-induced cytidine deaminase (AID);

\section{SUMMARY}

1. Introduction

2. Structure of FOXO family members

3. Physiological functions of FOXO proteins

4. Implications of FOXO proteins in pathological processes and associated diseases

5. Critical functions of FOXO transcription factors in stem cells and their role in cancer stem cells

6. Expression of FOXO family members in various tissues

7. FOXOs and microRNAs

8. Conclusions and future perspectives

\section{Introduction}

The Forkhead box (FOX) proteins represent a wide family of transcription factors that display an extraordinary functional diversity, regulating a variety of critical biological processes ${ }^{1,2}$. FOX 


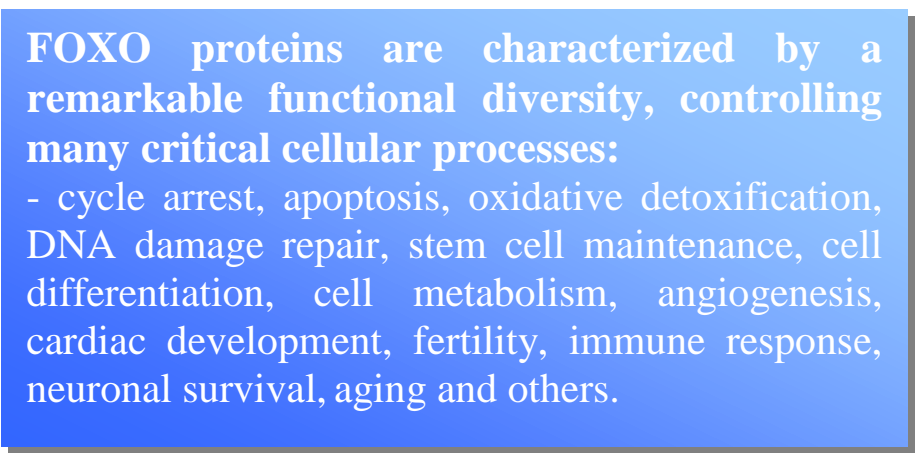

proteins are well known to control the following physiological procceses: apoptosis, cell-cycle, cellular metabolism, immune response, differentiation, development (such as cardiac development) or aging. FOX proteins are also involved in various pathologies, such as cancer, diabetes and neurodegenerative diseases ${ }^{3,4}$.

The first forkhead transcription factor was first identified in 1989, and its function was related to the development of the anterior and posterior gut of the Drosophila embryo. The "forkhead" name was given because of the two spiked-head structures found in the embryos of the Drosophila Melanogaster forkhead mutant presenting modifications of the gut formation ${ }^{5}$. One year later, the sequence comparison between forkhead and mammalian hepatocyte-enriched transcription factor HNF-3A showed a conserved 110-aminoacid DNA binding domain, bringing evidence that forkhead proteins are a new class of transcription factors ${ }^{6}$.

Hence, forkhead transcription factors are defined by their winged-helix DNA binding domain, a conserved structure called „Forkhead box", the symbol FOX being assigned to all vertebrate forkhead transcription factors, according to the revised nomenclature ${ }^{7}$.

Since its discovery, numerous forkhead genes have been identified in a broad range of organisms, from yeast and worms to humans ${ }^{2}$. Interestingly, up to now, FOX genes have not been identified in plants ${ }^{8}$. However, an update published in 2010 reported that are 50 FOX genes identified and classified in the human genome and 44 in the mouse genome ${ }^{9}$. Therefore, a standard nomenclature system was required for this extended number of discovered factors. In 2000, Daniel E. Martinez and his team established Fox Nomenclature Committee, the first step towards an unified nomenclature for the winged-helix / forkhead transcription factors. The Committee has changed the initial terms for the forkhead proteins (e.g. FREAC - Forkhead RElated Activator; fkh Drosophila gene fork head) ${ }^{7}$. Currently, based on phylogenetic analysis, FOXO genes are classified in subclasses that range from FOXA to FOXS to yield 23 subclasses in total ${ }^{10,} 11,12,13$. Each subclass has several members noted with an arabic number. While for human forkhead proteins abbreviations have all letters in uppercase (e.g., FOXD3), for mouse only the first letter is capitalized (e.g., Foxd3) and for all other chordates the first and subclass letter are in uppercase (e.g., FoxD3) ${ }^{7}$.

One of the largest and the most important subclass of FOX family is represented by FOXO (Forkhead box, subclass $\mathrm{O}$ ) transcription factors. FOXO transcription factors (FOXOs) are characterized by the same conserved DNA binding domain that define the family of forkhead proteins ${ }^{1}$. However, FOXOs share an additional unique 5 amino acid sequence insertion within the DNA binding domain that is not present in other forkhead proteins ${ }^{14}$.

Only one FOXO transcription factor is known in invertebrates (named abnormal dauer formation protein 16/DAF-16 in the nematode worm Caenorhabditis elegans and dFOXO in the fruit fly Drosophila melanogaster), while in mammals four FOXO proteins encoded by four different genes were identified: FOXO1, FOXO3, FOXO4 and FOXO6 ${ }^{15}$.

Initially, FOXO1 transcription factor (previously known as FKHR-forkhead in rhabdomyosarcoma) was identified through its involvement in chromosomal translocations $\mathrm{t}(2 ; 13)$ and $\mathrm{t}(1 ; 13)$ in alveolar rhabdomyosarcoma tumors due to PAX3/7-FKHR fusion transcript ${ }^{16,17}$. A few years later, FOXO3 (previously known as FKHRL1 - forkhead in rhabdomyosarcoma like protein 1) was characterized and named, based on similarities to $\mathrm{FKHR}^{18}$. The gene for FOXO4 was described as being fused to MLL transcription factor as a result of the $t(X ; 11)$ chromosomal translocation in acute lymphoblastic leukemia, therefore, the initial term for FOXO4 was AFX (The acute leukemia fusion gene located on chromosome $\mathrm{X})^{19}$.

FOXO proteins are considered unique cellular targets, regulating a wide variety of critical cellular processes, such as: apoptosis, oxidative stress, DNA damage repair, cell cycle, stem cell 
proliferation and maintenance, metabolism, angiogenesis, vascular tone, cardiovascular development, fertility, immune response and neuronal survival ${ }^{4,20}$. The aim of this review is to discuss the most recent advances in elucidating the functions, structure and transcriptional regulation of Forkhead Box $\mathrm{O}$ transcription factors, both in physiological and pathological conditions. The advances in understating the mechanism of FOXOs regulation of stem cells, cancer stem cells and how non-coding RNAs are regulated and regulate the function of FOXO genes/protein are presented.

\section{Structure of FOXO family members}

In humans, the primary structure of the FOXO proteins is characterized by a length of approximately 655-675 amino acid residues (aa) for FOXO1 (655 aa) and FOXO3 (673 aa), and a shorter sequence of approximately 500 amino acids for FOXO4 (505 aa) and FOXO6 (492 aa) $)^{21,22,23,24}$. All members of the FOXO family consist of four domains: a forkhead DNA-binding domain (DBD), a nuclear localization signal (NLS), a nuclear export sequence (NES) and a C-terminal transactivation domain ${ }^{25}$ (Figure 1).

The forkhead DNA-binding domain (DBD), also called the forkhead box, is described as a ,winged helix" due to the butterfly-like aspect on X-ray crystallography and nuclear magnetic resonance ${ }^{26}$. Analysis of the amino acid sequences alignment of FOXO proteins revealed a highly conserved DNA binding domain among all the members of the broader group of forkhead transcription factors, but also among species, in eukaryotic organisms, from yeast to humans ${ }^{3,27}$. Moreover, several studies point out that forkhead DBD is not the only region in the FOXO molecule that is highly conserved. Similarities were also observed in the N-terminal region near the first AKT/protein kinase $\mathrm{B}$ (PKB) phosphorylation site (Thr24 for FOXO1 and Thr32 for FOXO3), the region containing NLS, and sequences from C-terminal transactivation domain $^{25}$.

As mentioned above, the forkhead domains in FOXO subclass of FOX family are similar to the forkhead regions of other subclasses. For example, structural similarities have been proven in the core region of FOXO3 compared to FOXA3, FOXK1 and FOXP2 ${ }^{28}$. The forkhead/winged helix motif is a shared sequence between subclasses of FOXO, of around 100 amino acids that folds into three alphahelices (H1, H2 and H3), three beta-strands (S1, S2 and S3) and two wing-like loops (W1 and W2). The structure has a H1 - S1 - H2 - H3 - S2 - W1 S3 - W2 topology and the strands S1, S2 and S3 interact with each other forming a beta-sheet. While the $\mathrm{N}$-terminal part of the domain is formed by a cluster of three alpha-helices, the C-terminal half consists of beta strands $\mathrm{S} 2$ and $\mathrm{S} 3$ and two large loops (wings W1 and W2) ${ }^{25}$. The main DNA recognition site is represented by the highly

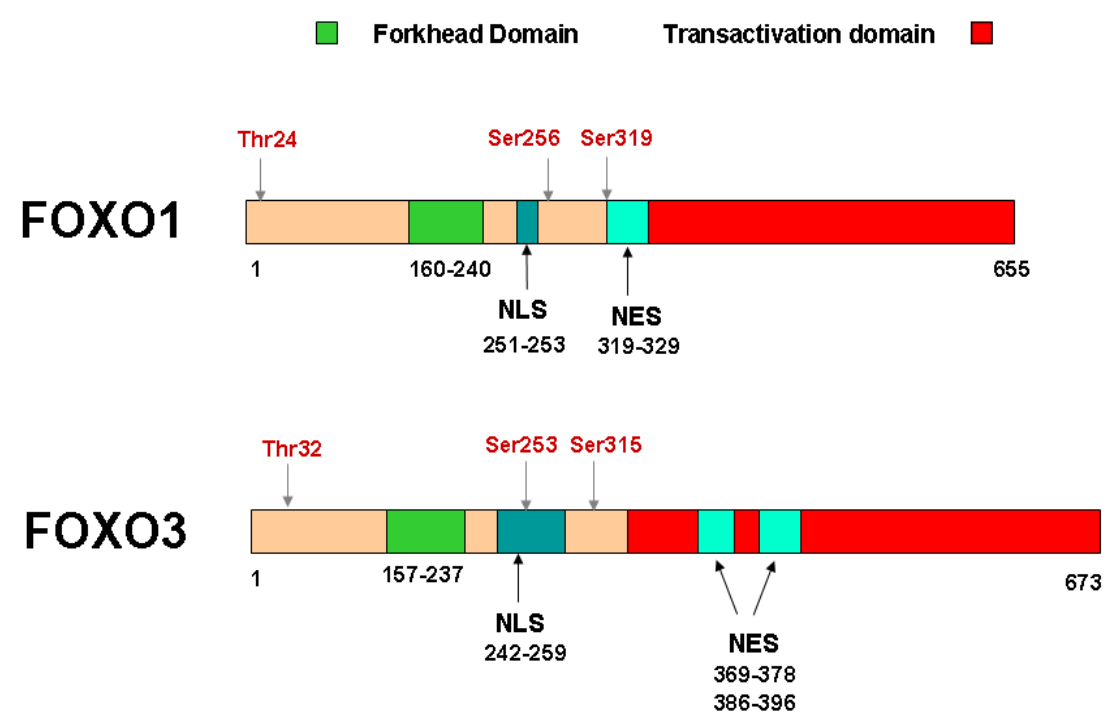

Figure 1: Structure of FOXO family members

FOXO1 and FOXO3 are exemplified here. In humans, the primary structure of the FOXO proteins is characterized by a length of approximately 655-675 amino acid residues (aa) for FOXO1 (655 aa) and FOXO3 (673 aa), while FOXO4 has 505 aa and FOXO6 492 aa All members of the FOXO family consist of four domains: a forkhead DNA-binding domain (DBD), a nuclear localization signal (NLS), a nuclear export sequence (NES) and a C-terminal transactivation domain. 
conserved helix $\mathrm{H} 3$ of forkhead DNA-binding domain. The stability of forkhead DBD - DNA complexes is increased by the more variable regions of the $\mathrm{DBD}$, including $\mathrm{H} 1$, the region between $\mathrm{H} 2$ and $\mathrm{H} 3$, wing $\mathrm{W} 1$ and $\mathrm{C}$-terminal segment ${ }^{25}$.

Although the FOXO forkhead box is clearly related to those found in other forkhead genes, all FOXO members contain an aditionally segment of five amino acid (198-GDSNS-202) between helices $\mathrm{H} 2$ and $\mathrm{H} 3$, that creates a small extra loop, forming a coil structure in the FOXO3 DBD, and a short helix in the FOXO4 DBD ${ }^{28,29}$.

This is important in sequence-specific interactions with DNA-binding sites ${ }^{30}$.

FOXO proteins mediate transcriptional activation through binding to the conserved consensus core motif TTGTTTAC in the DNA ${ }^{31}$. They bind DNA through a FOXO-recognized element with a T/C-G/A-A-A-A-C-A-A consensus sequence in the forkhead DBD (C-terminal) ${ }^{26}$. There are fourteen protein-DNA contacts described, which mediate the activation/inhibition of FOXO's target genes, such as Bim, TRAIL, p27, p21 and catalase. The main recognition site is the $\alpha$-helix $\mathrm{H} 3^{32}$.

\section{Physiological functions of FOXO proteins}

Forkhead proteins function as transcription factors that bind to DNA through their forkhead domain in order to upregulate or downregulate the expression of a tremendous number of target genes ${ }^{20}$.

Hence, the FOXO transcription factors control the expression of a wide spectrum of genes that regulate essential physiological cellular processes, such as cell death/cell survival, cell cycle, cell proliferation, cell differentiation/development, angiogenesis, cell metabolism, stress response and stem cell maintenance $33,34,35,36,37,38$ (Figure 2). Moreover, FOXOs are also involved in a wide range of pathological cellular processes, such as cancer, neurodegenerative diseases (Parkinson's disease, Alzheimer), diabetus mellitus, cardiac failure, atherosclerosis, hypertension and anovulation $39,40,41,42,43,44,45,46$.

Differences between functions and regulatory mechanisms of FOXO1 and FOXO3 proteins are considered to be partially redundant, with several exceptions. For example, AKT phosphorylates all FOXO family members, inducing their translocation into the cytoplasm and inactivation, while PP2A dephosphorylates part of the AKT phosphorylation sites in FOXO1 and FOXO3, reactivating them ${ }^{47}$. Several particular differences regarding the regulatory kinases, E3 ligases or other important enzymes and regulators exist. Thus, their activity is in part controlled by different mechanisms $^{31}$.

\section{Apoptosis}

FOXO transcription factors regulate the expression of multiple pro-apoptotic and anti-apoptotic proteins, and they have the ability to induce apoptosis by activating either intrinsic or extrinsic pathways of apoptosis ${ }^{48,49,50,51,52}$. Moreover, the consensus FOXO recognition element (FRE) $(\mathrm{G} / \mathrm{C})(\mathrm{T} / \mathrm{A}) \mathrm{AA}(\mathrm{C} / \mathrm{T}) \mathrm{AA}$ - which differs from that of other forkhead proteins, seems to have a very important role in both apoptotic pathways, since matching functional FRE sites have been identified in the promoters of FOXO target genes encoding Fas ligand (FasL), insulin like growth factorbinding protein 1 (IGFBP1), the apoptotic regulator Bcl-2 interacting mediator of cell death (Bim) and others ${ }^{30}$.

FOXO triggers the mitochondria-dependent intrinsec apoptotic pathway through upregulation of multiple pro-apoptotic Bcl-2 family members, such as Puma, Bim, NOXA, BNIP3, and downregulation of the anti-apoptotic Bcl-2 family member Bcl-xL ${ }^{48,49,50,51,52}$. The expression of the anti-apoptotic protein $\mathrm{Bcl}-\mathrm{xL}$ is suppressed by FOXO proteins, such as FOXO4, after increasing the expression of the transcriptional repressor Bcl6 , in order to trigger apoptosis ${ }^{52}$.

Both FOXO-induced expression of the proapoptotic Bcl-2 family members and FOXOdownmodulated anti-apoptotic Bcl-2 family members lead to apoptosis due to mitochondrial outer membrane permeabilization (MOMP), as a response to intracellular stress, growth factor deprivation or other factors ${ }^{53}$. These mitochondrial modifications result in release of cytochrome c, Smac/DIABLO and Omi/HtrA2 from mitochondria, subsequently triggerring downstream caspases activation ${ }^{54,55}$. Apaf 1 binds cytochrome c forming a complex named Apoptosome, required for caspase 9 activation (initiator caspase) $^{54}$. Caspase 9 activation further activates the effector caspases, such 3,6 or 7 , triggering caspase cascade ${ }^{54}$. 
FOXO proteins are also able to induce apoptosis by activating the receptor-dependent extrinsic pathway of apoptosis. They induce the upregulation of the death receptor ligands FasL and TRAIL, promoting an autocrine and/or paracrine action of these death ligands on the death receptors ${ }^{56}$. Fas signaling pathway is important in apoptosis induction through the extrinsic pathway, since Jurkat cells lacking several critical components of Fas pathway fail to induce FOXOdependent cell death ${ }^{57}$. Upregulation of tumor necrosis factor related apoptosis inducing ligand (TRAIL) by increased levels of FOXO1 or FOXO3 in cancer cells, such as prostate carcinoma cells, leads to apoptosis ${ }^{58}$. Thus, binding of Fas ligand (FasL) and TRAIL to their receptors (Fas/CD95/APO-1 for FasL and DR4, DR5 for TRAIL) triggers a death-inducing signaling complex (DISC) with a subsequent activation of caspases, mainly initiator caspase 8 and effector caspase 3, leading to apoptosis ${ }^{59}$. Moreover, FOXO transcription factors directly regulate the expression of tumor necrosis factor receptorassociated death domain (TRADD). Activation of
FOXO proteins by PI3K-AKT pathway inhibitors results in increased expression of TRADD protein $^{60}$. TRADD is an important adaptor protein interacting with TNFR1 and Fas receptors, mediating apoptosis and NFkB pathway activation $^{61}$.

\section{Cell cycle and proliferation}

Under normal physiological conditions, cyclins and their associate cyclin dependent kinases (CDKs) are very important for the progression of the cell cycle ${ }^{62}$. In response to DNA damage, FOXO transcription factors increase the expression levels of the CDK inhibitors binding to cyclin/CDK complexes, such as p21 (also known as CDK inhibitor 1) and p27 (Kip1) $)^{63,64}$. CDK inhibitors together with FOXO-induced inhibition of Cyclins expression act by stopping the cell cycle at different checkpoints in order to repair the DNA damage or to remove the damaged cell ${ }^{65}$. For example, a study performed on 32D murine myeloid cells and on $\mathrm{BaF} 3$ murine pre-B-cell lines brings evidence that endogenous FOXO proteins are required to enforce cell cycle checkpoints after

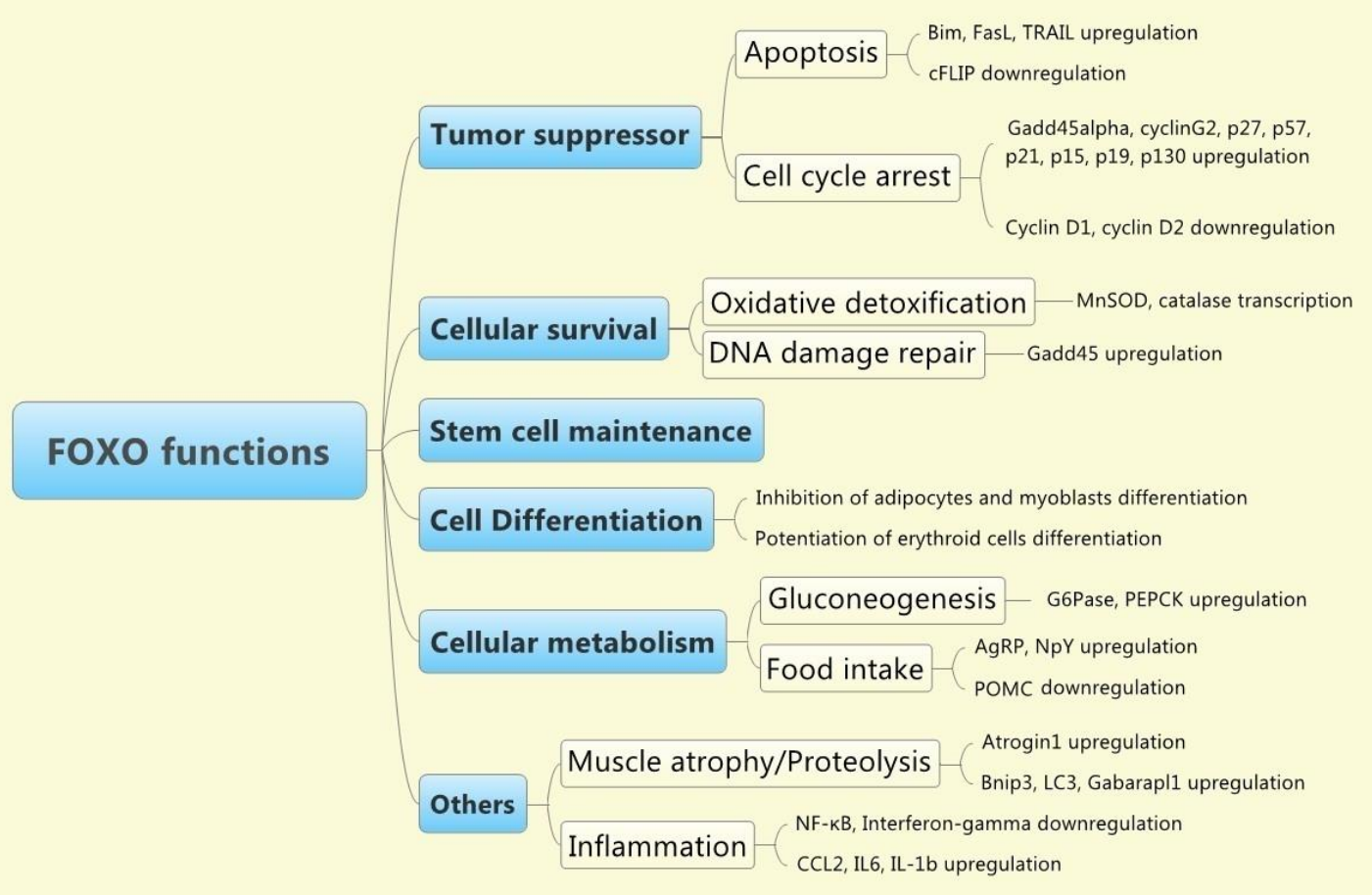

Figure 2: Functions of FOXO family of transcription factors

FOXO transcription factors control the expression of a wide spectrum of genes that regulate essential physiological cellular processes, such as cell death/cell survival, cell cycle, cell proliferation, cell differentiation/development, angiogenesis, cell metabolism, stress response and stem cell maintenance. 
DNA damage ${ }^{33}$.

The cell cycle arrest at $\mathrm{G} 1 / \mathrm{S}$ transition is induced by FOXO by upregulating the negative regulators of the G1/S phase, such as the CDK inhibitors: $\mathrm{p} 27^{\mathrm{KIP} 1}, \mathrm{p} 57^{\mathrm{KIP} 2}, \mathrm{p} 21^{\mathrm{CIP} 1 / \mathrm{WAF} 1}$ (CIP/KIP family), $\mathrm{p} 15^{\mathrm{INK}}, \mathrm{p} 19^{\mathrm{INK}}$ (INK family) and the retinoblastoma protein family member p130 ${ }^{27}$.Also, FOXO decreases the positive regulators, such as cyclin D1, or cyclin D2, blocking the G1/S transition ${ }^{66}$. Additionally, FOXO increases the expression of negative regulators such as Gadd45alpha and cyclin G2, resulting in cell cycle arrest at $\mathrm{G}_{2} / \mathrm{M}^{66}$. Surprisingly, FOXO proteins act as transcription factors for PLK1 expression during cell cycle, PLK1 being critical in promoting G2-M phase transition, $\mathrm{M}$ phase progression and end of mitosis $^{67}$. A complete knock-down of FOXO protein levels induces an arrest in cell cycle, suggesting that a basal, low levels of FOXOs activity is required for the cell cycle progression ${ }^{67}$. Surprisingly, in specific settings, FOXO may actually serve as a promoter of proliferation. For example, neutrophils isolated from FOXO3 deficient mice show high levels of FasL expression and apoptosis, revealing that FOXO3 may represses FasL expression in neutrophils, leading to proliferation in this type of cells ${ }^{68}$. FOXO1 was also shown to positively influence proliferation induction in pancreatic $\beta$ cells in vitro, under low nutritional circumstances. The mechanisms implicated in this process are not completely understood. However, the induction of Cend1 gene transcription, which encodes Cyclin D1, may at least partially be involved. Cyclin D1 represents one of the earliest cell cycle-related events, being critical for the $\mathrm{G} 1$ to $\mathrm{S}$ phase progression during the cell cycle ${ }^{34}$.

Thus, FOXO proteins coordinate the expression of multiple important cell cycle regulators, in order to block the G0/G1, G1/S or the G2/M transitions during cell cycle when needed, such as after DNA damage. However, a basal level of FOXO proteins is required for G2-M cell cycle transition, when FOXO-dependent PLK1 expression seems to be necessary. These results suggest that FOXO proteins have to be tightly regulated and are important and sensitive regulators of cell cycle, proliferation and other critical cellular processes.

\section{Differentiation and development}

FOXO proteins play an important role in regulating differentiation of a wide variety of tissues. It is well known that FOXOs can control the differentiation of precursor cells into muscle, adipose tissue or blood cells. Interestingly, FOXOs effect on differentiation is context dependent and sometimes FOXO isoform dependent. While FOXO3 promotes differentiation of erythroid cells, FOXO1 suppresses the differentiation of precursor cells in adipose and muscle tissues ${ }^{69}$. FOXOs can also suppress bone formation by inhibiting Wnt- $\beta$ catenin-TCF signaling. Wnt signaling is known to stimulate bone formation ${ }^{70}$.

Moreover, FOXO proteins are required for maintenance of somatic/adult stem cells, such as hematopoietic stem cells, and they also regulate cancer stem cells ${ }^{71}$ (see details in Chapter 5).

\section{Cellular Metabolism}

Metabolic signaling mediated by forkhead transcription factors is conserved among multiple species, including but no limited to mammals, Drosophila melanogaster and Caenorhabditis elegans $^{20}$. It was first noticed for the FOXO homolog named Dauer Formation-16 (DAF-16), in the Caenorhabditis elegans worm ${ }^{72}$.

FOXO proteins are involved in critical physiological processes that regulate cellular metabolic activity in many organs, such as liver, pancreas, adipose tissue and hypothalamus ${ }^{73,74,75,76}$. In the liver, FOXO1 forms a complex with another transcription factor, the liver specific PGC1alpha, in order to induce gluconeogenesis by upregulating G6Pase and PEPCK genes. This is important for maintaining glucose homeostasis ${ }^{73}$. Confirming these results, loss of hepatic FOXO genes in mice induces a downmodulation of gluconeogenesis and an upregulation of glycolysis ${ }^{77}$. In addition, ectopic expression of FOXO1 in rat primary hepatocytes increases apocIII, an inhibitor of lipoprotein lipase, suggesting that FOXO1 is involved in regulating the lipid metabolism ${ }^{78}$. Recently, nicotinamide phosphoribosyltransferase (Nampt) gene was described to be a new transcriptional target gene of FOXOs for regulating hepatic triglyceride levels ${ }^{79}$. In pancreas, FOXO1 plays an important role in the maintenance of beta cell function, but also in the development of the pancreas, through repression of the pancreatic transcription factor $\mathrm{Pdx} 1^{74}$. Aditionally, FOXO1 increases the food intake by 
upregulating $\mathrm{AgRP}$ and $\mathrm{NpY}$, and by downregulating POMC in hypothalamus, antagonizing the anorexigenic hormone leptin ${ }^{76,80}$. Recently, G-protein-coupled receptor Gpr17 was described to be a FOXO1 target that activates AgRP, suggesting a new mechanism for FOXO1AgRP mediated food intake that might provide a new treatment for obesity ${ }^{81}$.

All these results establish FOXO proteins as important regulators of cellular metabolism and potential target in metabolic related diseases.

\section{Stress Response, DNA Damage Repair and Longevity}

FOXO transcription factors function as sensors for reactive oxygen species (ROS) and play an important role in cellular resistance to stress, increasing cellular survival. FOXO proteins are able to protect the cell from oxidative damage, decreasing the availability of ROS. They stimulate the expression of certain genes responsible for the ROS inactivation, such as the antioxidant enzymes manganese superoxide dismutase (MnSOD), that catalyzes the conversion of superoxide to hydrogen peroxide, and catalase, that converts hydrogen peroxide into water and oxygen ${ }^{27}$. Studies on human cardiac fibroblasts revealed that FOXO also modulate the antioxidant enzyme peroxiredoxin III, fighting against cell damage induced by oxidative stress. Concomitant peroxiredoxin III knockdown and FOXO3 knockdown resulted in higher levels of hydrogen peroxide in response to serum starvation, as compared to peroxiredoxin III knockdown only ${ }^{82}$. Other FOXO transcriptional targets (Figure 3), such as sterrole carrier proteins (SCPs), are now known to play an important role during the defence against oxidative stress. SCPs are implicated in protecting fatty acids from peroxidation $^{83}$. FOXO proteins are also able to increase DNA repair, inducing a cell cylce arrest at G2/M checkpoint, in order to provide time for repairing the DNA damage. One of the transcriptional target of FOXO, implicated not only in cell cycle arrest but also in DNA repair and cell survival in response to cellular stress, is Gadd $45^{84}$. Similarly, DDB1 gene protein product is able to repair the DNA damage through upregulation by $\mathrm{FOXO}^{69}$.

FOXOs regulate the longevity of the cell mainly by increasing resistance to stress, modulating the DNA repair process and maintaining the stem cells ${ }^{27}$. The lifespan extension is an important function of FOXO that is conserved among several species. A well studied example is the role of FOXO homologous DAF-16 (Caenorhabditis elegans) in aging ${ }^{85}$. Loss of FOXO3 in human skin fibroblasts results in aging specific morphological changes, suggesting that FOXO3 is necessary for maintenance or promotion of cellular longevity ${ }^{86}$. Moreover, loss of FOXO3 activity leads to decreased MnSOD and enhanced cell injury in vascular smooth muscle explanted from aged mice, due to limied ROS inactivation ${ }^{87}$. Thus, cellular lifespan maintenance requires a certain level of FOXOs activity and this is mainly achieved by inactivation of AKT activity ${ }^{88}$. FOXO proteins do not only play an important protective role during senescence/aging, but also during exercise. It was previously suggested that FOXOs may at least partially be involved in the exerciseinduced beneficial cardiac effects. Interestingly, exercise induces an upregulation of $\mathrm{FOXO} 3$ and SIRT1 in the heart, with subsequent increased MnSOD, catalase and GAD45alpha, and decreased Cyclin D2, suggesting the protective role of FOXO proteins ${ }^{89}$.

Interestingly, other studies revealed that, in conditions of oxidative stress, FOXO3 is also able to induce apoptosis by triggering a Fas-mediated death pathway in cultured motoneurons, by activating TRAIL, BH3-only proteins Noxa and Bim, and by promoting pro-apoptotic activity of $\mathrm{p} 53^{20}$. Additional reports suggest that suppression of FOXO proteins expression during oxidative stress can be protective to some extent for cells, since protein inhibition or gene knockdown of FOXO1 and FOXO3 decreases the ischemic infarct size in the brain, protects the metabotropic glutamate receptors during vascular injury, enhances pancreatic $\beta$-cell or neuronal survival through NAD + precursors and provide trophic factor protection with erythropoietin (EPO) and neurotrophins ${ }^{20}$. This suggests that while a certain level of FOXO3 activation is required in cellular stress resistance, sustained activation or activation over a threshold of FOXO3 is detrimental and may induce apoptosis. Thus, FOXO3 plays an important role in cellular decision during stress, helping the cells to survive by multiple mechanisms (such as DNA repair, ROS inactivation etc) and inducing apoptosis when DNA or cellular damage can't be repaired. 
Figure 3: Selective list of FOXO regulated transcriptional targets

\begin{tabular}{|c|c|c|c|c|}
\hline Function & $\begin{array}{c}\text { FOXO's transcriptional } \\
\text { target }\end{array}$ & $\begin{array}{c}\mathrm{Up} / \\
\text { downregulation }\end{array}$ & FOXOs & References \\
\hline $\begin{array}{c}\text { Intrinsic } \\
\text { pathway of } \\
\text { apoptosis }\end{array}$ & $\begin{array}{l}\text { Puma } \\
\text { Bim } \\
\text { NOXA } \\
\text { BNIP3 } \\
\text { Bcl-xL }\end{array}$ & $\begin{array}{l}\text { upregulation } \\
\text { upregulation } \\
\text { upregulation } \\
\text { upregulation } \\
\text { downregulation }\end{array}$ & $\begin{array}{l}\text { FOXO3 } \\
\text { FOXO3 } \\
\text { FOXO1 } \\
\text { FOXO3 } \\
\text { FOXO4 }\end{array}$ & $\begin{array}{l}48 \\
49 \\
50 \\
51 \\
52\end{array}$ \\
\hline $\begin{array}{c}\text { Extrinsic } \\
\text { pathway of } \\
\text { apoptosis }\end{array}$ & $\begin{array}{l}\text { FasL } \\
\text { TRAIL } \\
\text { TRADD }\end{array}$ & $\begin{array}{l}\text { upregulation } \\
\text { upregulation } \\
\text { upregulation }\end{array}$ & $\begin{array}{c}\text { FOXO1, } 3 \\
\text { FOXO1, } 3 \\
\text { FOXO1 }\end{array}$ & $\begin{array}{c}59,27 \\
59,27 \\
60\end{array}$ \\
\hline Cell cycle & $\begin{array}{l}\text { p21 } \\
\text { p27 } \\
\text { p57 } \\
\text { p19 } \\
\text { p130 } \\
\text { cyclin D1 } \\
\text { cyclin D2 } \\
\text { Gadd45alpha } \\
\text { cyclin G2 } \\
\text { PLK1 }\end{array}$ & $\begin{array}{c}\text { upregulation } \\
\text { upregulation } \\
\text { upregulation } \\
\text { upregulation } \\
\text { upregulation } \\
\text { downregulation } \\
\text { downregulation } \\
\text { upregulation } \\
\text { upregulation } \\
\text { upregulation }\end{array}$ & $\begin{array}{c}\text { FOXO4 } \\
\text { FOXO3 } \\
\text { FOXO1 } \\
\text { FOXO1, } 3 \\
\text { FOXO1, 3, } 4 \\
\text { FOXO1 } \\
\text { FOXO1 } \\
\text { FOXO3, } 4 \\
\text { FOXO1, 3, } 4 \\
\text { FOXO1 }\end{array}$ & $\begin{array}{l}63 \\
64 \\
27 \\
27 \\
27 \\
66 \\
66 \\
27 \\
27 \\
67 \\
\end{array}$ \\
\hline Metabolism & $\begin{array}{l}\text { G6Pase } \\
\text { PEPCK } \\
\text { apocIII } \\
\text { Nampt } \\
\text { Pdx1/IPF1 } \\
\text { AgRP } \\
\text { NpY } \\
\text { POMC } \\
\text { Gpr17 } \\
\end{array}$ & $\begin{array}{l}\text { upregulation } \\
\text { upregulation } \\
\text { downregulation } \\
\text { upregulation } \\
\text { downregulation } \\
\text { upregulation } \\
\text { upregulation } \\
\text { downregulation } \\
\text { downregulation } \\
\end{array}$ & $\begin{array}{l}\text { FOXO1 } \\
\text { FOXO1 } \\
\text { FOXO1 } \\
\text { FOXO1 } \\
\text { FOXO1 } \\
\text { FOXO1 } \\
\text { FOXO1 } \\
\text { FOXO1 } \\
\text { FOXO1 } \\
\end{array}$ & $\begin{array}{l}73 \\
73 \\
78 \\
79 \\
74 \\
76 \\
80 \\
76 \\
81 \\
\end{array}$ \\
\hline $\begin{array}{c}\text { Stress response, } \\
\text { DNA damage } \\
\text { repair }\end{array}$ & $\begin{array}{l}\text { MnSOD } \\
\text { Catalase } \\
\text { PRDX } \\
\text { Sterrole Carrier Proteins } \\
\text { DDB1 }\end{array}$ & $\begin{array}{l}\text { upregulation } \\
\text { upregulation } \\
\text { upregulation } \\
\text { upregulation } \\
\text { upregulation }\end{array}$ & $\begin{array}{l}\text { FOXO3 } \\
\text { FOXO3 } \\
\text { FOXO3 } \\
\text { FOXO3 } \\
\text { FOXO3 }\end{array}$ & $\begin{array}{l}27 \\
27 \\
82 \\
83 \\
69\end{array}$ \\
\hline Other functions & $\begin{array}{l}\text { Mxi1/Mad2 } \\
\text { Estrogen receptor alpha } \\
\text { Runx2/CCD } \\
\text { LC3 } \\
\text { Bnip3 } \\
\text { Atrogin } 1 \\
\text { IL-7R } \\
\text { CD62L }\end{array}$ & $\begin{array}{l}\text { upregulation } \\
\text { upregulation } \\
\text { upregulation } \\
\text { upregulation } \\
\text { upregulation } \\
\text { upregulation } \\
\text { upregulation } \\
\text { upregulation }\end{array}$ & $\begin{array}{l}\text { FOXO3 } \\
\text { FOXO3 } \\
\text { FOXO3 } \\
\text { FOXO3 } \\
\text { FOXO3 } \\
\text { FOXO1, } 3 \\
\text { FOXO1 } \\
\text { FOXO1 }\end{array}$ & $\begin{array}{c}101 \\
39 \\
70 \\
106 \\
106 \\
20,27 \\
91 \\
91\end{array}$ \\
\hline microRNAs & $\begin{array}{l}\text { miR-30d } \\
\text { miR-506 } \\
\text { miR-508 } \\
\text { miR-513c } \\
\text { miR-513a-1 } \\
\text { miR-513a-2 } \\
\text { miR-106b } \\
\text { miR-93 } \\
\text { miR-25 }\end{array}$ & $\begin{array}{l}\text { upregulation } \\
\text { upregulation } \\
\text { upregulation } \\
\text { upregulation } \\
\text { upregulation } \\
\text { upregulation } \\
\text { downregulation } \\
\text { downregulation } \\
\text { downregulation }\end{array}$ & $\begin{array}{l}\text { FOXO3 } \\
\text { FOXO1 } \\
\text { FOXO1 } \\
\text { FOXO1 } \\
\text { FOXO1 } \\
\text { FOXO3 } \\
\text { FOXO3 } \\
\text { FOXO3 }\end{array}$ & $\begin{array}{l}138 \\
139 \\
139 \\
139 \\
139 \\
139 \\
140 \\
140 \\
140\end{array}$ \\
\hline
\end{tabular}




\section{Immune response}

FOXO proteins play a central role in maintaining the immune response of the human body. Cell type-specific deletions of FOXO1 and/or FOXO3 in mice revealed an important role of FOXO proteins in regulating immunological homeostasis and tolerance, by controlling the function and development of $\mathrm{B}$ and $\mathrm{T}$ lymphocytes. Thus, FOXO1 and FOXO3 are essential transcription factors involved in early B cell development and peripheral $\mathrm{B}$ cell function, since early deletion of FOXO1 blocked B cell differentiation at the pro-B cell stage. This is due to a defect in interleukin 7 receptor alpha (IL-7Ralpha) expression. Deletion of FOXO1 in peripheral B cells was associated with defective expression of both CD62L and AID, with subsequent failure in class-switch recombination and reduced $\mathrm{IgG}$ production upon immunization. Moreover, it is known that the PI3K-AKT-mediated inactivation of FOXO1 is essential for the optimal proliferation of B cells, while ectopic expression of PI3K-independent variants of FOXO1 or FOXO3 (active triple mutants at the AKT phosphorylation sites) resulted in cell cycle arrest and increased cell death in B cells ${ }^{90}$. Another study on mice with $\mathrm{T}$ cell-specific deletion of FOXO1 showed a decreased expression of IL-7 receptor on mature T-cells, suggesting that IL7-R is a transcriptional target of FOXO1, which is mediating through binding with IL-7 the survival and homeostatic proliferation of peripheral $\mathrm{T}$ cell ${ }^{91}$.

Excesive inflammatory cells may become harmful for the human body through the generation of ROS and through the production of cytokines. Studies performed on mice deficient of FOXO3 ilustrated lymphoproliferation, inflammation of the salivary glands, lung, and kidney, and increased activity of helper $\mathrm{T}$ cells. These observations demonstrate the beneficial role of FOXO proteins in human body, by preventing $\mathrm{T}$ cell hyperactivity ${ }^{20}$. Also, it was demonstrated that miR-182 has a central role in the late phase of clonal expansion of the helper $\mathrm{T}$ lymphocytes, by inducing IL-2 which is able to inactivate FOXO1. FOXO1 was found to be a suppressor of proliferation in resting helper $\mathrm{T}$ lymphocytes and, in order to allow proliferation, $\mathrm{T}$ cell activation via TCR/CD28 and IL-2R signaling must inhibit FOXO1 ${ }^{90}$. Other studies reported that $\mathrm{T}$ cells derived from Bim and Puma deficient mice were resistant to apoptosis after IL-2 deprivation, demonstrating that $\mathrm{FOXO} 3$, through upregulation of Bim, Puma and $\mathrm{p} 27^{\mathrm{Kip} 1}$ is important for the induction of cell cycle arrest and apoptosis of $\mathrm{T}$ cells, in the absence of cytokines ${ }^{48}$. FOXO proteins may be benefical for autoimmune disorders by inducing a Fas mediated apoptosis that target activated $\mathrm{T}$ cells, followed by a decrease in cytokine stimulation in patients with autoimmune lymphoproliferative syndromes ${ }^{20}$.

\section{Implications of FOXO proteins in pathological processes and associated diseases}

FOXO proteins play an important role not only during physiological cellular processes, but also in few pathologies, such as cancer. FOXOs are well known tumor suppressor proteins.

Although FOXO proteins protect the human body by playing a central role in a wide range of mainly physiological functions (as described earlier), under some circumstances, FOXO's roles can become harmful for the human cells. This is because FOXO is also involved in a number of pathological functions, such as inflammation and muscle atrophy. For example, apoptosis places FOXO proteins on the good side when it leads to tumor suppression. However, cellular apoptosis can become itself a significant component for pathology in diseases such as neurodegenerative disease, diabetes mellitus (DM), and cardiovascular injury $40,41,92,93$.

\section{Cancer: FOXO proteins are tumor suppressors}

FOXO proteins are inactivated in a wide variety of malignancies, eiher posttranslational (mainly by PI3K-AKT mediated phosphorlation) or by fusion mutations (such as PAX3-FOXO1; MLL-FOXO3, MLL-FOXO4) ${ }^{94,95}$. Inactivation of FOXO by PI3K-AKT pathway activation is a common feature of many malignancies, such as prostate cancer, breast cancer, leukemia and glioblastoma ${ }^{69}$. Conditional deletion of FOXO family members in mice leads to the lymphomas and hemangiomas, which suggests that loss of FOXOs maintains or promotes survival of tumor cells ${ }^{96}$. FOXOs loss or inactivation is known to play an important role in cancer tumorigenesis or progression, in vivo ${ }^{97}$. For example, a recent study described a significant correlation between low expression of FOXO3 and a poor prognosis for gastric cancer patients, bringing evidence that FOXO3 could be a valuable prognostic biomarker for patients with gastric 
cancer $^{98}$. In addition, FOXO3 overexpression was shown to reduce motility, invasiveness, and aggressiveness in estrogen receptor $\alpha$-positive $(\mathrm{ER} \alpha+)$ breast cancer cells ${ }^{39}$.

FOXO proteins exert their tumor suppressor functions predominantly by promoting cell cycle arrest, apoptosis, ROS inactivation and DNA repair, through expression of their target genes ${ }^{47,99}$. For instance, FOXO3-induced expression of Bim, a pro-apoptotic member of the Bcl-2 family of proteins induced a caspase-dependent cell death in several types of cancers, such as in chronic leukemias, breast and gastric cancers ${ }^{27}$. Similarly, FOXO-induced TRAIL and NOXA expression induces apoptosis in many malignancies, including leukemias ${ }^{100}$.

Interestingly, FOXO3 can also inhibit the protooncogene c-myc, indirectly controlling the transcription of a wide set of target genes implicated in cell survival, cell cycle, apoptosis and tumorigenesis. Myc is a transcription factor and a well known promoter of survival, proliferation and tumorigenesis, being found upregulated in a large variety of malignancies. FOXO3 induces the expression of Mxi1, which is a transcriptional suppressor of c-Myc, thereby inactivating Myc-dependent transcription. Mxi1 also plays a role in FOXO-induced proliferation inhibition. Similarly, FOXO-induced suppression of proliferation in colon carcinoma cell lines may involve the Mad/Mxd family of proteins, which are known Myc target genes ${ }^{101}$.

Noteworthy, activation of FOXO proteins not only induces cell cycle arrest or apoptosis, but also a differentiation program. In chronic myeloid leukemia (CML), FOXO3 can induce CML leukemic cells differentiation, by inhibiting the expression of Id1 (Inhibitor of DNA binding 1). CML is characterized by the presence of the BcrAbl fusion protein, which is a constitutive active kinase, controlling many crucial downstream pathways implicated in cell cycle, proliferation, apoptosis and cell adhesion. Bcr-Abl activates PI3K-AKT pathway, inactivating FOXO proteins and their pro-apopotic and cell cycle arrest signals $^{27}$. The use of the Tyrosine Kinase Inhibitors (TKIs) and of the proteasome inhibitor Bortezomib results in inhibition of Bcr-Abl activity and its downstream pathways, with a subsequent activation of FOXO proteins ${ }^{102}$.
TKIs treatment induces a FOXO-dependent suppression of Id1 expression, leading to K562 Bcr-Abl positive cell line differentiation. Thus, Bcr-Abl can maintain the leukemic state not only by promoting proliferation, cell cycle progression and inhibiting apoptosis, but by also inhibiting FOXO-mediated differentiation ${ }^{27}$.

Inflammation (rheumatoid arthritis, osteoarthritis, systemic lupus erythematosus)

It was shown that loss of functional FOXO proteins lead to inflammatory cell activation in several disorders, with the subsequent cellular damage, through oxidative stress and excess of cytokines. Inactivation of $\mathrm{FOXO} 3$ in $\mathrm{T}$ lymphocytes, as well as inactivation of FOXO1 and FOXO4 in synovial macrophages in patients with rheumatoid arthritis and osteoarthritis result in inflammatory cell activation. In addition, loss of FOXO proteins may be a potential etiology for systemic lupus erythematosus (SLE) and rheumatoid arthritis, since FOXO1 gene transcript levels are downregulated in peripheral blood mononuclear cells of these patients ${ }^{20}$. A link between inflammation, insulin resistance and FOXO transcription factors was previously suggested when downregulated FOXO1 decreased the levels of $\mathrm{C} / \mathrm{EBP}$ beta transcription factor in adipocytes, with the subsequent reduction in expression of the pro-inflammatory cytokines CCL2 (chemokine ligand 2) and IL- $6^{103}$. Thus, FOXO1 indirectly might induce an inflammatory status of the adipose tissue, responsible for the insulin resistance in type 2 diabetes. Yet, there are studies that describe the ability of FOXO proteins to directly induce inflammation through upregulation of the inflammatory cytokine IL$1 b^{104}$. However, further experiments are required in order to clearly understand the context related mechanisms of FOXO-dependent modulation of inflammation.

\section{Muscle atrophy by proteolysis}

Muscle atrophy appears in a variety of diseases, including cancer, diabetes and sepsis, and is characterized by accelerated proteolysis that can be induced through two pathways: the ubiquitin proteasome pathway and through lysosomal pathway, as a consequence of autophagy ${ }^{27}$. Studies revealed that FOXO proteins can induce muscle atrophy, characterized by decreased muscle 
function ${ }^{105}$. Thus, FOXO proteins have been shown to increase the transcription of key regulators of both lysosomal and proteasomal proteolysis: the autophagy followed by the lysosomal proteolysis is stimulated by upregulation of Bnip3, LC3, and Gabarapl1, while the proteasomal proteolysis is induced by increasing the ubiquitin ligase atrogin 1 . It was also shown that FOXO3 activity is both required and sufficient for induction of autophagy in muscle cells, since studies performed on adult muscle fibers from mice show that the ectopic expression of an active FOXO3 mutant leads to lysosomal proteolysis after formation of autophagosomes, while the knockdown of FOXO3 in these muscles fibers blocked autophagosome formation after starvation ${ }^{106,107}$.

Autophagy has a critical role in maintaining the cellular and metabolic homeostasis. It seems that the metabolic status of the cell strongly influences this process in both normal cells and cancer cells, despite the profound differences in their metabolism ${ }^{108}$. In cancer cells, ATP is predominantly produced through the constitutive activation of aerobic glycolysis, process that is modulated by the transcription factor $\operatorname{HIF} 1 \alpha^{108}$. Since p38 $\alpha$ is required to maintain the levels of HIF $1 \alpha$ target genes, researchers demonstrated that in colorectal cancer cells, the inhibition of p38a causes a rapid drop in ATP levels, with an acute energy need which activates FOXO3 in an AMPKdependent manner, in order to induce autophagy, cell cycle arrest and cell death in these cells ${ }^{96,108}$.

Moreover, the knockdown of FOXO3 was sufficient to induce hypertrophy in cultured neonatal rat cardiomyocytes. In these cells, stimulation with insulin inhibits FOXO3 function, with subsequent downregulation of the antioxidant enzyme catalase and increased levels of ROS, that in low levels may act as second messengers for intracellular signaling, making possible the increase in cell size ${ }^{109}$. Atrogin 1, upregulated by FOXO1 and FOXO3, plays important roles in cardiovascular system, since mice lacking atrogin1 are susceptible to cardiac hypertrophy ${ }^{20}$. FOXO proteins are inducing atrophy of differentiated cardiac and skeletal muscle cells through protein synthesis inhibition, which leads to a decrease in cell size ${ }^{69}$. In skeletal muscle, this mechanism involves myostatin, a FOXO transcriptional target and a secreted molecule that can induce atrophy by protein synthesis inhibition ${ }^{110}$.

\section{Other pathological processes: metabolic, cardiovascular and reproductive disorders}

FOXO1 might be implicated in the development or progression of type 2 diabetes, since increased FOXO1 expression in diabetic mouse liver is associated with increased expression of PEPCK and G6Pase, and inhibition of FOXO1 activity downregulated both PEPCK and G6Pase expression and normalized the blood glucose levels. Thus, FOXO1-mediated expression of G6Pase and PEPCK is critical for gluconeogenesis in the liver during fasting, but its deregulation may be involved in diabetes etiology ${ }^{111}$. Physiological functions of FOXO take place under certain circumstances, since sometimes the ability to maintain the proper control is overwhelmed ${ }^{20}$. Experiments on insulin-producing mouse pancreatic beta cells (betaTC-6) show that chronic exposure to high glucose activates FOXO transcription factors and leads to upregulation of endogenous inflammatory cytokines interleukin1beta (IL-1beta) and suppressors of cytokine signalling (SOCS). These events trigger the activation of caspase-3 with subsequent apoptosis, suggesting a new mechanism that leads to the destruction of endocrine pancreas in type 2 diabetes $^{92}$. Also, exposure to high glucose of the cardiac microvascular endothelial cells (CMECs) isolated from hearts of adult rats show that FOXO transcription factors leads to reactive oxygen species (ROS) accumulation and apoptosis, suggesting that FOXOs might be involved in microvascular complications of diabetes ${ }^{93}$. FOXO is also involved in insulin resistance and metabolic syndrome, since the activation of FOXO1 in cardiomyocytes leads to increased AKT activity and attenuated cellular response to insulin, followed by decreased glucose uptake ${ }^{112}$.

Interestingly, clinical studies regarding metabolic status profile on age-related diseases, fertility, fecundity and mortality revealed higher HbA1c levels and increased mortality risk associated with specific haplotypes of $\mathrm{FOXO} 1^{113}$.

FOXO proteins are also activated in an attempt to protect the human body against the oxidative stress resulted due to hyperglycemia that leads to increased production of ROS in endothelial cells, liver cells, and pancreatic $\beta$-cells. This hyperglycemia-dependent ROS increase leads to a subsequent development of insulin resistance and 
significant neurodegenerative and cardiovascular diseases in the patients with diabetus mellitus ${ }^{20}$.

FOXOs are necessary for endothelial cell development and angiogenesis, since mice that are deficient in FOXO1 lack development of the vascular system and die by embryonic day eleven $^{114}$. In addition, FOXO1 and FOXO3 were shown to be the most abundant FOXO isoforms in mature endothelial cells, having also an important role in the regulation of postnatal vessel formation, not only in the embryogenesis ${ }^{36}$. Unfortunately, angiogenesis is not only involved in critical physiological processes, such as embryogenesis and postnatal vessel formation, but it is also involved in pathological events, such as chronic inflammation and tumor growth ${ }^{115}$. Thus, it is fascinating how the angiogenesis mediated by FOXO proteins may become a negative element for the organism, antagonizing the tumor suppresor's main function through new vessel formation, that can lead to tumor cell growth ${ }^{116}$.

FOXO3 was associated with both cardiomyocyte survival after oxidative stress and heart muscle loss with subsequent ventricular dysfunction ${ }^{43,117}$. FOXOs are activated after AKT inhibition by insulin or other factors, leading to Atrogin-1 induction, which results in a suppression of heart muscle cell size ${ }^{43}$.

FOXO3 proteins seem to inhibit the vascular smooth muscle cell proliferation and growth in a rat balloon carotid arterial injury model, suggesting a role of FOXOs in the regulation of vascular tone and systemic arterial blood pressure, preventing or at least lessening the effects of atherosclerosis and hypertension $^{118}$. Also, decreased FOXO1 expression due to high flow states in vessels leads to proliferation of vascular smooth muscle cells, vascular neointimal hyperplasia, and subsequent hypertension $^{45}$. Moreover, experiments on lowdensity lipoprotein $(\mathrm{Ldl})$ receptor knockout mice resulted in the prevention of atherosclerosis when the triple ablation of FOXO1, FOXO3 and FOXO4 was induced in endothelial cells ${ }^{44}$. Interestingly, the same experiment on myeloid cells lead to more severe atherosclerosis compared to the controls, explained by authors through increased proliferation of granulocyte-monocyte progenitors and high levels of inducible nitric oxide synthase (iNOS) and oxidative stress, which predispose to atherosclerosis $^{119}$.
Noteworthy, analysis of mouse oocytes revealed overexpressed FOXO3 transcription factors in primordial and early primary follicles, but downregulated FOXO in primary and more developed follicles, suggesting that FOXO proteins also have reproductive functions, modulating oocyte and follicular cell maturation. To confirm the hypothesis, constitutively active FOXO3 was induced in transgenic mouse oocytes in primary and more developed follicles, which affected the oocyte growth and follicular development, leading to anovulation and luteinization of unruptured follicles, with subsequent infertility ${ }^{46}$. In addition, FOXO3 and FOXO1 mutations were detected in a small percentage of womens with premature ovarian failure $^{120}$.

\section{Critical functions of FOXO transcription factors in stem cells and their role in cancer stem cells}

Involvement of FOXO family of transcription factors in stem cells self-renewal, survival, proliferation and differentiation is currently under investigation. FOXOs have been shown to play critical functions in maintaining self-renewal potential and quiescence of hematopoietic stem cells, however, the mechanisms of these processes are not yet well understood ${ }^{1,69}$. Recent reports show that FOXO-mediated regulation of cell cycle, oxidative stress and apoptosis plays an important role in these processes ${ }^{69}$.

Stem cells are characterized by the capacity of self-renewing and the ability to differentiate ${ }^{121}$. They are necessary in maintenance and propagation of several adult tissues, including but not limited to blood, skin and gastro-intestinal epithelium. Adult stem cells or cells with stem cell properties were also found in other critical organs/systems, such as the central nervous system and the lung ${ }^{69}$.

Previous studies suggested that hematopoietic stem cells are sensitive to reactive oxygen species (ROS) levels. FOXO family members are known to play a central role in ROS detection and in inducing an adaptative response after ROS exposure, by inducing the expression of critical enzymes that neutralise ROS, such as catalase and manganase superoxide dismutase (MnSOD). Interestingly, FOXO1, FOXO3, and FOXO4 inactivation leads to an upregulation of ROS levels in hematopoietic stem cells and their death ${ }^{121}$. 
Deletion of these three FOXO family members in mice revealed their importance in controlling ROS in stem cells, in vivo ${ }^{27}$. While the number of hematopoietic stem cells in bone marrow of FOXO-deficient mice is low, an increase in myeloid progenitor cells in blood is observed. Moreover, the repopulation ability is decreased in the absence of FOXOs and the treatment of FOXO-deficient mice with N-Acetylcysteine (NAC) at least partially rescued these effects ${ }^{27}$.

Thus, persistent AKT activation, which induces inactivation of FOXO transcription factors by AKT-mediated phosphorylation, results in ROS-induced cell death. This is due to the fact that the cells can't synthesize the FOXO-dependent ROS neutralizing factors catalase and $\mathrm{MnSOD}^{121}$. Between FOXO family members, the most important regulator of hematopoietc stem cells survival and self-renewal is FOXO3, since FOXO3 knockdown induces hematopoietic stem cells depletion $^{121}$. ROS neutralizing agent NAcetylcysteine (NAC) can rescue hematopoietic stem cells quiescence and at least partially resque their ROS-induced loss ${ }^{121}$. All these results suggest that FOXO1, FOXO3 and FOXO4-induced resistance to ROS is critical in maintaining homeostasis of hematopoietic stem cells in bone marrow $^{27}$.

PTEN tumor suppressor was revealed as an important modulator of hematopoietic stem cells self-renewal and survival. PTEN is a major inhibitor of AKT activation. Depletion of PTEN, induces AKT activation and subsequent FOXO inactivation. It is likely that FOXOs mediate at least a part of the PTEN effects on hematopoietic stem cells ${ }^{121}$.

Although FOXO3 was established as the most important FOXO family member regulator of hematopoietic stem cell's self-renewal, FOXO1 is critical for the human embryonic stem cells (hESC) pluripotency maintenance. FOXO1induced SOX2 and OCT4 expression is one of the mechanisms responsible for this process. Interestingly, in embryonic stem cells AKT is not the major regulator of $\mathrm{FOXO}^{71}$.

Fascinating, a recent study brings evidence that FOXO is a critical regulator of stem cell maintenance in Hydra vulgaris, a member of the phylogenetically old animal phyla Cnidaria, which has been suggested to be biologically immortal due to the unlimited self-renewal capacity of their stem cells ${ }^{38,122}$.

FOXO transcription factors are not only required for maintenance of somatic stem cells, but they also play an important role in cancer stem cells ${ }^{71}$. Recent reports provided evidence that in many types of malignancies, such as leukemia, colon, or gastro-intestinal malignanciens, a small population of cells similar to stem cells exists ${ }^{121}$. These cells, called cancer stem cells, have the potential of forming new tumors. Notably, most of the time, the cancer stem cells are resistant to current cancer treatments, and these therapies may result in cancer stem cells enrichment. These cells serve as a starting point in cancer recurrence ${ }^{121}$. Similarities between stem cells and cancer stem cells were best described in the hematopoietic system, where similar surface markes and signal transduction patterns were described between the hematopoietic stem cells and leukemia-initiating cells ${ }^{121}$.

Presented results have not only implications in uncovering the stem cells/cancer stem cells regulation, self-renewal and differentiation, but also for the development of novel therapeutic strategies in cancer, degenerative diseases and many other pathologies ${ }^{71}$.

\section{Expression of FOXO family members in various tissues}

FOXO family members are expressed in almost every tissue of the human body, including the nervous system, cardiovascular system, reproductive system of males and females, lung, liver, spleen, pancreas, thymus, and skeletal muscle. However, each member of the FOXO family has its own expression pattern, since they are not equally expressed in all tissues ${ }^{20}$. FOXO1 is better represented in adipose tissue ${ }^{27}$. FOXO3 has the highest expression in liver, but it is also being predominantly expressed in heart, brain, kidneys, and ovaries, while FOXO4 is found mainly in the muscle and heart ${ }^{20,27}$. The newest member of the transcription family, FOXO6, is present in the brain. The association of this member with other tissues is still a matter of study ${ }^{123}$.

Cell lines (immortalized and/or cancer cells) are some of the most used and useful tools for studying the structure, function, regulation and expression of proteins in general, and FOXO family members in particular. FOXO members 
expression in different cell lines (including NCI 60 group of cell lines) is partially known ${ }^{124,125}$. FOXO1 is found to be expressed at high levels in IGROV 1 (human ovarian carcinoma cells), astrocyte cells, RL 7 (human follicular lymphoma cells), HT29 (human colon carcinoma cells) and HEK 293 (human embryonic kidney cells). FOXO3 high levels were especially found in SHSYSY (human neuroblastoma cell line), RPMI 8226 (human myeloma cells), MCF 7 (human breast adenocarcinoma cell line), LNCAP (human prostate adenocarcinoma cells), U251 (human glioma cells). FOXO4 is mostly expressed in CCRT CEM (human leukemia cell line), ALVA 31 (human prostate tumor cells), HL 60 (human promyelocytic leukemia cell line), TK 10 (human renal adenocarcinoma cells), MALME 3M (human malignant melanoma cell line) and HEP G2 (human hepatocellular carcinoma cells) ${ }^{126,127,128}$.

Knowing the qualitative and quantitative expression pattern of FOXO family members is important in elucidating their functions and regulation. Thus, databases summarizing these patterns in various tissues and cell lines are very helpful and necessary. For example, BioGPS presents experimental results showing the mRNA expression levels of a wide number of genes in most of the human tissues and many (mostly human) cell lines ${ }^{126,127,128 .}$.

Regulation of FOXOs expression is not yet well understood. P300 was shown to control FOXO1 gene expression by binding to the proximal region of the FOXO1 promoter (CRE tandem sites) ${ }^{129}$. Non-coding RNAs were shown to suppress translation of FOXO family members in various tissues and contexts. In particular, the microRNAs-dependent inhibition of FOXO1 and FOXO3 expression is better studied and is summariez below, in chapter 7 .

However, the main transcription factors implicated in FOXOs expression are not well understood. Interestingly, methylation of FOX promotors induces suppression of their expression. As an example, promoter methylation induced by BRAF results in inactivation of FOX genes expression $^{130}$.

\section{FOXO and non-coding RNAs}

The miRNAs are 18-28 nucleotide-long noncoding RNA molecules with an important role in post- transcriptional regulation of protein expression that regulate a variety of cellular processes, including cell differentiation, cell cycle progression and apoptosis. These miRNAs can function as oncogenes or tumor suppressors, and oncogenic miRNAs (oncomiRs) are upregulated in cancer cells. In cancer, miRNAs were found to be situated both upstream and downstream of the carcinogenesis process and modified expression of some miRNAs is the outcome of carcinogenic transformation or progression, revealing that miRNAs may be potential diagnostic or prognostic tools in cancer. ${ }^{131}$ For instance, microRNAs gained a special attention in melanoma studies and the altered pattern of miRNA in melanoma seems to be related to apoptosis (miR-15b), cell cycle (miR-193b) and invasion/metastasis (miR-182) ${ }^{132}$.

\section{FOXOs regulation by microRNAs}

The microRNA (miRNA)-mediated regulation of FOXO transcription factors was demonstrated by several groups within the last three years. miR-182 has been shown to specifically target FOXO transcription factors irrespective of cell type, since miR-182 seems to target FOXO3 in melanoma cells, FOXO1 in breast cancer cells and FOXO1 in activated helper $\mathrm{T}$ (Th) lymphocytes ${ }^{90}$. Thus, in melanoma cells, miR-182 modulate the expression of both FOXO3 and microphthalmia-associated transcription factor (MITF). The inhibition of miR182 by anti-miRs (blocking antisense oligonucleotides) hindered melanoma cell migration and triggered their apoptosis ${ }^{90}$. In breast cancer cells, FOXO1 was coordinately targeted by miR-27a, miR-96, and miR-182, while the inhibition of each miRNA resulted in induced levels of FOXO1 and reduced breast cancer cell survival $^{90}$. miR-182 also targets FOXO1 in osteoblasts lineage cells in order to inhibit osteoblast proliferation and differentiation, repressing the osteogenesis ${ }^{133}$.

Many other microRNAs were shown to regulate FOXOs activity and functions, including apoptosis or cell cycle. MiR-96 has been shown to regulate FOXO1-induced apoptosis in transitional cell carcinoma ${ }^{134}$. Also, increased expression of miR-96 in breast cancer cells have been shown to downregulate FOXO3 transcription factor with consequent induction of cell proliferation ${ }^{135}$. Also, increased miR-96, miR-182 and miR-183 
downregulate the expression of FOXO1 transcription factor in classical Hodgkin lymphoma (cHL) cell lines, suggesting that decreased FOXO1 expression is involved in lymphomagenesis ${ }^{136}$. Moreover, a recent study performed on DU145 and LNCaP human prostate cancer cells show that upregulated microRNA-370 induces proliferation due to downregulation of the FOXO1 transcription factor $^{137}$. In addition, miR-155, which is highly induced in mature activated $\mathrm{T}$ and $\mathrm{B}$ cells and in $\mathrm{T}_{\text {reg }}$ cells, has recently been shown to target FOXO3 in $\mathrm{T}$ cells, but it remains to be shown whether FOXO3 via miR-155 contributes to the observed phenotypes in $\mathrm{B}$ and $\mathrm{T}$ lymphocytes ${ }^{90}$.

New strategies to modulate FOXO expression may now be developed since the discovery of miRNAs targeting FOXO transcription factors ${ }^{90}$. However, some difficulties may appear in the miRNA-based therapeutic manipulation of FOXO transcription factors. For example, a single miRNA may target hundreds of genes among FOXOs, and the therapeutic manipulation of a specific miRNA could have unanticipated adverse effects by influencing whole gene networks, while having only moderate effects on FOXO genes ${ }^{90}$. Since delivery of miR-182 mimics could induce lymphoproliferative disease or other forms of cancer by systemic repression of FOXO transcription factors, another challenge in the miRNA-FOXO therapeutic manipulation is the specific delivery of the miRNA into the target cell, in order to avoid adverse effects in other cell types or tissues ${ }^{90}$.

\section{microRNAs functions mediated by FOXOs}

Several microRNAs were identified as being targets of FOXO transcription factors. An AKT FOXO - miR-30d signaling pathway was recently identified. After inhibition of AKT, activated FOXO3 leads to upregulation of miR-30d. miR$30 \mathrm{~d}$ acts as a tumor suppressor in renal cell carcinoma, further inhibiting the oncoprotein metadherin (MTDH) ${ }^{138}$.

Another recent study shows that FOXO1 stimulates the expression of a microRNA cluster located on a $\mathrm{X}$ chromosome, in a direct manner, dependent on RNA polymerase II, but not on the de novo protein synthesis. Thus, FOXO1 upregulates miR-506, miR-508, miR-513c, miR513a-1, miR-513a-2. Also, the same study shows that inhibition of PI3K-AKT axis in LNCaP and MCF7 human carcinoma cell lines is followed by increased miR-506. As suggested by authors, miRNAs could be valuable biomarkers of FOXO activity $^{139}$.

A study performed on primary cultures of neural stem/progenitor cells (NSPCs) from adult mice show that the expression levels of the miR106b 25 cluster members (miR-106b, miR-93, and miR-25) is modulated by FOXO3 transcription factors in a complex manner ${ }^{140}$. The precursors of the miR-106b 25 cluster members are located on $\mathrm{Mcm} 7$ gene. FOXO3 directly binds to the first intron of this gene, modulating the expression of the microRNAs. Thus, FOXO3 transcription factors could be an important tool in preventing the loss of neurogenesis during aging ${ }^{140}$. Further studies are needed to completely understand the regulation of microRNAs expression by activated FOXO proteins.

\section{Conclusions and future perspectives}

FOXO transcription factors and tumor suppressors are ubiquitously expressed in the human body, with some specific differences between its members. As resumed above, FOXO proteins are characterized by a remarkable functional diversity, being implicated in regulation of many critical cellular functions, such as cell cycle arrest, apoptosis, oxidative detoxification, DNA damage repair, stem cell maintenance, cell differentiation, cell metabolism, angiogenesis, cardiac development, aging and others.

FOXO proteins play an important role not only during physiological cellular processes, but also in few pathologies, such as cancer. They are well known tumor suppressors proteins. Although FOXO proteins protect the human body by playing a central role in a wide range of mainly physiological functions, under some circumstances, FOXO's roles can become harmful for the human cells. This is because FOXO is also involved in a number of pathological functions, such as inflammation, muscle atropy, and a number of physiological functions that become harmful for the organism. For example, apoptosis places FOXO proteins on the good side when it leads to tumor suppression, but in some cases cellular apoptosis can become itself a significant component for pathology in diseases such as 
neurodegenerative disease, diabetes mellitus (DM), and cardiovascular injury.

Interestingly, while excessive FOXO levels induce cell cycle arrest and cell death, complete knock-down of FOXOs leads to cell cycle progression impairment, suggesting that certain levels of FOXO activation are required for cell cycle progression. Moreover, FOXO proteins play a variety of roles in the cells dependending on the context.

In addition, FOXO have critical implications in both normal and cancer stem cell biology. FOXO proteins are required for adult stem cells maintenance. Novel strategies to modulate FOXO expression and activity may now be developed since the discovery of novel FOXO regulators and non-coding RNAs (such as microRNAs) targeting FOXO transcription factors.

Thus, FOXO family of transcription factors and tumor suppressors are crucial regulators of cell fate and of critical normal or pathological cell decisions. A better understanding of their structure, critical functions and regulation may contribute to the development of novel therapies for cancer and other FOXO-related diseases.

\section{Acknowledgement \& Conflict of interest}

This manuscript was supported by Research

Project PN 09.33 - 01.01 (GRD).

There are no conflicts of interest.

\section{References}

1. Yang JY, Hung MC. Deciphering the role of forkhead transcription factors in cancer therapy. Curr Drug Targets. 2011; 12(9):1284-1290. PMID: 21443462.

2. Jagani Z, Singh A, Khosravi-Far R. FoxO tumor suppressors and BCR-ABL-induced leukemia: a matter of evasion of apoptosis. Biochim Biophys Acta. 2008; 1785(1):63-84. PMID: 17980712.

3. Tuteja G, Kaestner KH. SnapShot: forkhead transcription factors I. Cell. 2007; 130(6):1160. PMID: 17889656.

4. Maiese K, Chong ZZ, Shang YC. "Sly as a FOXO": new paths with Forkhead signaling in the brain. Curr Neurovasc Res. 2007; 4(4):295-302. PMID 18045156.

5. Weigel D, Jürgens G, Küttner F, Seifert E, Jäckle $\mathrm{H}$. The homeotic gene fork head encodes a nuclear protein and is expressed in the terminal regions of the Drosophila embryo. Cell. 1989; 57(4):645-58. PMID: 2566386.

6. Weigel D, Jäckle H. The fork head domain: a novel DNA binding motif of eukaryotic transcription factors? Cell. 1990; 63(3):455-6. PMID: 2225060.

7. Kaestner KH, Knochel W, Martinez DE. Unified nomenclature for the winged helix/forkhead transcription factors. Genes Dev. 2000; 14(2):1426. PMID: 10702024.

8. Wotton KR, Shimeld SM. Comparative genomics of vertebrate Fox cluster loci. BMC Genomics. 2006; 7:271. PMID: 17062144.

9. Jackson BC, Carpenter C, Nebert DW, Vasiliou V. Update of human and mouse forkhead box (FOX) gene families. Hum Genomics. 2010; 4(5):345-52. PMID: 20650821.

10. Mazet F, Yu JK, Liberles DA, Holland LZ, Shimeld SM. Phylogenetic relationships of the Fox (Forkhead) gene family in the Bilateria. Gene. 2003; 316:79-89. PMID: 14563554.

11. Heglind M, Cederberg A, Aquino J, Lucas G, Ernfors P, et al. Lack of the central nervous system- and neural crest-expressed forkhead gene Foxs 1 affects motor function and body weight. Mol Cell Biol. 2005; 25(13):5616-25. PMID: 15964817.

12. Katoh M, Katoh M. Germ-line mutation of Foxn5 gene in mouse lineage. Int J Mol Med. 2004; 14(3):463-7. PMID: 15289901.

13. Katoh M, Katoh M. Identification and characterization of human FOXN6, mouse Foxn6, and rat Foxn6 genes in silico. Int J Oncol. 2004; 25(1):219-23. PMID: 15202009.

14. Wang F, Marshall CB, Yamamoto $\mathrm{K}$, Li GY, Plevin MJ, et al. Biochemical and structural characterization of an intramolecular interaction in FOXO3a and its binding with p53. J Mol Biol. 2008; 384(3):590-603. PMID: 18824006.

15. Glauser DA, Schlegel W. The emerging role of FOXO transcription factors in pancreatic beta cells. J Endocrinol. 2007; 193(2):195-207. PMID: 17470511.

16. Davis RJ, D'Cruz CM, Lovell MA, Biegel JA, Barr FG. Fusion of PAX7 to FKHR by the variant $\mathrm{t}(1 ; 13)(\mathrm{p} 36 ; \mathrm{q} 14)$ translocation in alveolar rhabdomyosarcoma. Cancer Res. 1994; 54(11):2869-72. PMID: 8187070.

17. Galili N, Davis RJ, Fredericks WJ, Mukhopadhyay $\mathrm{S}$, et al. Fusion of a fork head domain gene to PAX3 in the solid tumour alveolar rhabdomyosarcoma. Nat Genet. 1993; 5(3):230-5. PMID: 8275086.

18. Anderson MJ, Viars CS, Czekay S, Cavenee WK, Arden KC.Cloning and characterization of three human forkhead genes that comprise an 
FKHR-like gene subfamily. Genomics. 1998 Jan 15;47(2):187-99. PMID: 9479491.

19. Borkhardt A, Repp R, Haas OA, Leis T, Harbott $\mathrm{J}$, et al. Cloning and characterization of AFX, the gene that fuses to MLL in acute leukemias with a $\mathrm{t}(\mathrm{X} ; 11)(\mathrm{q} 13 ; \mathrm{q} 23)$. Oncogene. 1997 Jan 16;14(2): 195-202. PMID: 9010221.

20. Maiese K, Chong ZZ, Hou J, Shang YC. The "O" class: crafting clinical care with FoxO transcription factors. Adv Exp Med Biol. 2009; 665:242-60. PMID - 20429429.

21. NCBI Protein Database. Forkhead box protein O1 [Homo sapiens]. Accession: NP_002006.2 GI: 9257222. Available at: http://www.ncbi.nlm.nih. gov/protein/NP_002006.2

22. NCBI Protein Database. Forkhead box protein O3 [Homo sapiens]. Accession: NP_963853.1 GI: 42519916. Available at: http://www.ncbi.nlm.nih. gov/protein/NP_963853.1

23. NCBI Protein Database. Forkhead box protein O4 [Homo sapiens]. Accession: AAI06762.1 GI: 76827750 Available at: http://www.ncbi.nlm.nih. gov/protein/AAI06762.1

24. NCBI Protein Database. Forkhead box protein O6 [Homo sapiens]. Accession: A8MYZ6.1

GI: 166988458 Available at: http://www.ncbi.nlm.nih. gov/protein/A8MYZ6.1

25. Obsil T, Obsilova V. Structure/function relationships underlying regulation of FOXO transcription factors. Oncogene. 2008; 27(16): 2263-75. PMID: 18391969.

26. Maiese K, Chong ZZ, Shang YC, Hou J. A "FOXO" in sight: targeting Foxo proteins from conception to cancer. Med Res Rev. 2009; 29(3):395-418. PMID: 18985696.

27. Van der Vos KE, Coffer PJ. The extending network of FOXO transcriptional target genes. Antioxid Redox Signal. 2011; 14(4):579-92. PMID: 20673124.

28. Tsai KL, Sun YJ, Huang CY, Yang JY, Hung $\mathrm{MC}$, et al. Crystal structure of the human FOXO3aDBD/DNA complex suggests the effects of posttranslational modification. Nucleic Acids Res. 2007; 35(20):6984-94. PMID: 17940099.

29. Weigelt J, Climent I, Dahlman-Wright K, Wikström M. Solution structure of the DNA binding domain of the human forkhead transcription factor AFX (FOXO4). Biochemistry. 2001; 40(20): 5861-9. PMID: 11352721.

30. Fu Z, Tindall DJ. FOXOs, cancer and regulation of apoptosis. Oncogene. 2008; 27(16):2312-9. PMID: 18391973.

31. Calnan DR, Brunet A. The FoxO code. Oncogene. 2008; 27(16):2276-88. PMID: 18391970.
32. Clark KL, Halay ED, Lai E, Burley SK. Co-crystal structure of the HNF-3/fork head DNA-recognition motif resembles histone H5. Nature. 1993; 364(6436):412-20. PMID: 8332212.

33. Lei H, Quelle FW. FOXO transcription factors enforce cell cycle checkpoints and promote survival of hematopoietic cells after DNA damage. Mol Cancer Res. 2009; 7(8):1294-303. PMID: 19671690.

34. Ai J, Duan J, Lv X, Chen M, Yang Q, et al. Overexpression of FoxO1 causes proliferation of cultured pancreatic beta cells exposed to low nutrition. Biochemistry. 2010; 49(1):218-25. PMID: 19938874.

35. Hess Michelini R, Doedens AL, Goldrath AW, Hedrick SM. Differentiation of CD8 memory T cells depends on Foxo1. J Exp Med. 2013; 210(6):1189-200. PMID: 23712431.

36. Potente M, Urbich C, Sasaki K, Hofmann WK, Heeschen C, et al, Involvement of Foxo transcriptional factors in angiogenesis and postnatal neovascularization. J Clin Invest. 2005 Sep;115(9): 2382-92. Epub 2005 Aug 11. PMID: 16100571.

37. Zhang W, Patil S, Chauhan B, Guo S, Powell DR, et al. FoxO1 regulates multiple metabolic pathways in the liver: effects on gluconeogenic, glycolytic, and lipogenic gene expression. J Biol Chem. 2006; 281(15):10105-17. PMID: 16492665.

38. Boehm AM, Khalturin K, Anton-Erxleben F, Hemmrich G, Klostermeier UC, et al. FoxO is a critical regulator of stem cell maintenance in immortal Hydra. Proc Natl Acad Sci U S A. 2012; 109(48):19697-702. PMID: 23150562.

39. Sisci D, Maris P, Cesario MG, Anselmo $\mathrm{W}$, Coroniti R, et al. The estrogen receptor $\alpha$ is the key regulator of the bifunctional role of $\mathrm{FoxO} 3 \mathrm{a}$ transcription factor in breast cancer motility and invasiveness. Cell Cycle. 2013; 12(21): 3405-20. PMID: 24047697.

40. Pino E, Amamoto R, Zheng L, Cacquevel M, Sarria $\mathrm{JC}$, et al. FOXO3 determines the accumulation of $\alpha$-synuclein and controls the fate of dopaminergic neurons in the substantia nigra. Hum Mol Genet. 2013 Nov 6. (Epub ahead of print). PMID:24158851.

41. Hong YK, Lee S, Park SH, Lee JH, Han SY, et al. Inhibition of JNK/dFOXO pathway and caspases rescues neurological impairments in Drosophila Alzheimer's disease model. Biochem Biophys Res Commun. 2012; 419(1):49-53. PMID: 22326868.

42. Del Guerra S, Lupi R, Marselli L, Masini M, Bugliani M, et al. Functional and molecular defects of pancreatic islets in human type 
2 diabetes. Diabetes. 2005; 54(3): 727-35. PMID:15734849.

43. Galasso G, De Rosa R, Piscione F, Iaccarino G, Vosa C, et al. Myocardial expression of FOXO3a-Atrogin-1 pathway in human heart failure. Eur J Heart Fail. 2010; 12(12):1290-6. PMID: 21098579.

44. Tsuchiya K, Tanaka J, Shuiqing Y, Welch CL, DePinho RA, et al. FoxOs integrate pleiotropic actions of insulin in vascular endothelium to protect mice from atherosclerosis. Cell Metab. 2012; 15(3):372-81. PMID: 22405072.

45. Goettsch W, Gryczka C, Korff T, Ernst E, Goettsch $\mathrm{C}$, et al. Flow-dependent regulation of angiopoietin2. J Cell Physiol. 2008; 214(2):491-503. PMID: 17960565.

46. Liu L, Rajareddy S, Reddy P, Du C, Jagarlamudi $\mathrm{K}$, et al. Infertility caused by retardation of follicular development in mice with oocyte-specific expression of Foxo3a. Development. 2007; 134(1):199-209. PMID:17164425.

47. Singh A, Ye M, Bucur O, Zhu S, Tanya Santos $\mathrm{M}$, et al. Protein phosphatase $2 \mathrm{~A}$ reactivates FOXO3a through a dynamic interplay with 14-3-3 and AKT. Mol Biol Cell. 2010; 21(6):1140-52. PMID:20110348.

48. You H, Pellegrini M, Tsuchihara K, Yamamoto $\mathrm{K}$, Hacker G, et al. FOXO3a-dependent regulation of Puma in response to cytokine/growth factor withdrawal. J Exp Med. 2006; 203(7):1657-63. PMID: 16801400.

49. Yang JY, Xia W, Hu MC. Ionizing radiation activates expression of FOXO3a, Fas ligand, and Bim, and induces cell apoptosis. Int J Oncol. 2006; 29(3):643-8. PMID: 16865280.

50. Valis K, Prochazka L, Boura E, Chladova J, Obsil T, et al. Hippo/Mst1 stimulates transcription of the proapoptotic mediator NOXA in a FoxO1dependent manner. Cancer Res. 2011; 71(3):94654. PMID: 21245099.

51. Lin A, Yao J, Zhuang L, Wang D, Han J, Lam EW; et al. The FoxO-BNIP3 axis exerts a unique regulation of mTORC1 and cell survival under energy stress. Oncogene. 2013 Jul 15. (Epub ahead of print). PMID: 23851496.

52. Tang TT, Dowbenko D, Jackson A, Toney L, Lewin DA, et al. The forkhead transcription factor AFX activates apoptosis by induction of the BCL-6 transcriptional repressor. $J$ Biol Chem. 2002; 277(16):14255-65. PMID: 11777915.

53. Brunelle JK, Letai A. Control of mitochondrial apoptosis by the Bcl-2 family. J Cell Sci. 2009; 122(Pt 4):437-41. PMID: 19193868.

54. Chen M, Guerrero AD, Huang L, Shabier Z, Pan $\mathrm{M}$, et al. Caspase-9 -induced mitochondrial disruption through cleavage of anti-apoptotic BCL2 family members. J Biol Chem. 2007; 282(46): 33888-95. PMID:17893147.

55. Plati J, Bucur O, Khosravi-Far R (2008) Dysregulation of apoptotic signaling in cancer: molecular mechanisms and therapeutic opportunities. J Cell Biochem 104(4): 1124-1149. PubMed: 18459149.

56. Marfè G, Tafani M, Fiorito F, Pagnini U, Iovane $\mathrm{G}$, et al. Involvement of FOXO transcription factors, TRAIL-FasL/Fas, and sirtuin proteins family in canine coronavirus type II-induced apoptosis. PLoS One. 2011; 6(11):e27313. PMID: 22087287.

57. Brunet A, Bonni A, Zigmond MJ, Lin MZ, Juo P, et al. Akt promotes cell survival by phosphorylating and inhibiting a Forkhead transcription factor. Cell. 1999; 96(6):857-68. PMID: 10102273.

58. Modur V, Nagarajan R, Evers BM, Milbrandt J. FOXO proteins regulate tumor necrosis factor related apoptosis inducing ligand expression. Implications for PTEN mutation in prostate cancer. $J$ Biol Chem. 2002; 277(49):47928-37. PMID: 12351634.

59. Knight MJ, Riffkin CD, Muscat AM, Ashley DM, Hawkins CJ. Analysis of FasL and TRAIL induced apoptosis pathways in glioma cells. Oncogene. 2001; 20(41):5789-98. PMID: 11593384.

60. Rokudai S, Fujita N, Kitahara O, Nakamura Y, Tsuruo T. Involvement of FKHR-dependent TRADD expression in chemotherapeutic druginduced apoptosis. Mol Cell Biol. 2002; 22(24): 8695-708. PMID: 12446787.

61. Bender LM, Morgan MJ, Thomas LR, Liu ZG, Thorburn A. The adaptor protein TRADD activates distinct mechanisms of apoptosis from the nucleus and the cytoplasm. Cell Death Differ. 2005; 12(5):473-81. PMID:15761471.

62. Lim S, Kaldis P. Cdks, cyclins and CKIs: roles beyond cell cycle regulation. Development. 2013; 140(15):3079-93. PMID: 23861057.

63. de Keizer PL, Packer LM, Szypowska AA, RiedlPolderman PE, van den Broek NJ, et al. Activation of forkhead box $\mathrm{O}$ transcription factors by oncogenic BRAF promotes p21cip1-dependent senescence. Cancer Res. 2010; 70(21):8526-36. PMID:20959475.

64. Rathbone CR, Booth FW, Lees SJ. FoxO3a preferentially induces p27Kip1 expression while impairing muscle precursor cell-cycle progression. Muscle Nerve. 2008; 37(1):84-9. PMID:17894357.

65. Huang H, Tindall DJ. CDK2 and FOXO1: a fork in the road for cell fate decisions. Cell Cycle. 2007; 6(8):902-6. PMID: 17457058. 
66. Huang H, Tindall DJ. Dynamic FoxO transcription factors. J Cell Sci. 2007; 120(Pt 15):2479-87. PMID: 17646672.

67. Alvarez B, Martínez-A C, Burgering BM, Carrera AC.Forkhead transcription factors contribute to execution of the mitotic programme in mammals. Nature. 2001 Oct 18; 413(6857): 744-7. PMID: 11607034.

68. Jonsson H, Allen P, Peng SL. Inflammatory arthritis requires Foxo3a to prevent Fas ligandinduced neutrophil apoptosis. Nat Med. 2005; 11(6): 666-71. PMID:15895074.

69. Tothova Z, Gilliland DG. FoxO transcription factors and stem cell homeostasis: insights from the hematopoietic system. Cell Stem Cell. 2007; 1(2):140-52. PMID: 18371346.

70. Iyer S, Ambrogini E, Bartell SM, Han L, Roberson PK, et al. FOXOs attenuate bone formation by suppressing Wnt signaling. J Clin Invest. 2013; 123(8): 3409-19. PMID: 23867625.

71. Zhang X, Yalcin S, Lee DF, Yeh TY, Lee SM, et al. FOXO1 is an essential regulator of pluripotency in human embryonic stem cells. Nat Cell Biol. 2011; 13(9):1092-9. PMID: 21804543.

72. Ogg S, Paradis S, Gottlieb S, Patterson GI, Lee L, et al. The Fork head transcription factor DAF-16 transduces insulin-like metabolic and longevity signals in C. elegans. Nature. 1997; 389(6654):9949. PMID: 9353126.

73. Puigserver P, Rhee J, Donovan J, Walkey CJ, Yoon $\mathrm{JC}$, et al. Insulin regulated hepatic gluconeogenesis through FOXO1-PGC-1alpha interaction. Nature. 2003; 423(6939):550-5. PMID: 12754525.

74. Kitamura T, Nakae J, Kitamura Y, Kido Y, et al. The forkhead transcription factor Foxo1 links insulin signaling to Pdx1 regulation of pancreatic beta cell growth. J Clin Invest. 2002; 110(12):183947. PMID: 12488434.

75. Nakae J, Cao Y, Oki M, Orba Y, Sawa H, et al. Forkhead transcription factor FoxO1 in adipose tissue tissue regulates energy storage and expenditure. Diabetes. 2008; 57(3):563-76. PMID: 18162510.

76. Kitamura T, Feng Y, Kitamura YI, Chua SC Jr, Xu AW, et al. Forkhead protein FoxO1 mediates Agrpdependent effects of leptin on food intake. Nat Med. 2006; 12(5):534-40. PMID: 16604086.

77. Xiong X, Tao R, DePinho RA, Dong XC. Deletion of hepatic FoxO1/3/4 genes in mice significantly impacts on glucose metabolism through downregulation of gluconeogenesis and upregulation of glycolysis. PLoS One. 2013; 8(8):e74340. PMID:24015318.

78. Altomonte J, Cong L, Harbaran S, Richter A, Xu $\mathrm{J}$, et al. Foxo1 mediates insulin action on apoC-
III and triglyceride metabolism. J Clin Invest. 2004; 114(10): 1493-503. PMID: 15546000.

79. Tao R, Wei D, Gao H, Liu Y, DePinho RA, et al. Hepatic FoxOs regulate lipid metabolism via modulation of expression of the nicotinamide phosphoribosyltransferase gene. J Biol Chem. 2011; 286(16):14681-90. PMID: 21388966.

80. Hong SH, Lee KS, Kwak SJ, Kim AK, Bai H, Jung MS, et al. Minibrain/Dyrk1a regulates food intake through the Sir2-FOXO-sNPF/NPY pathway in Drosophila and mammals. PLoS Genet. 2012; 8(8):e1002857. PMID:22876196.

81. Ren H, Orozco IJ, Su Y, Suyama S, GutiérrezJuárez R, et al. FoxO1 target Grp17 activates AgRP neurons to regulate food intake. Cell. 2012; 149(6):1314-26. PMID: 22682251.

82. Chiribau CB, Cheng L, Cucoranu IC, Yu YS, Clempus RE, et al. FOXO3 regulates peroxiredoxin III expression in human cardiac fibro blasts. J Biol Chem. 2008; 283(13):8211-7. PMID: 18195003.

83. Dansen TB, Kops GJ, Denis S, Jelluma N, Wanders RJ, et al. Regulation of sterol carrier protein gene expression by the forkhead transcription factor FOXO3a. J Lipid Res. 2004; 45(1):81-8. PMID: 14563822.

84. Tran H, Brunet A, Grenier JM, Datta SR, Fornace AJ Jr, et al. DNA repair pathway stimulated by the forkhead transcription factor FOXO3a through the Gadd45 protein. Science. 2002; 296(5567):530-4. PMID: 11964479.

85. Tullet JM, Araiz C, Sanders MJ, Benedetto A, Papatheodorou I, et al. DAF-16/FoxO Directly Regulates an Atypical AMP-Activated Protein Kinase Gamma Isoform to Mediate the Effects of Insulin/IGF-1 Signaling on Aging in Caenorhabditis elegans. PLoS Genet. 2014; 10(2):e1004109. PMID: 24516399.

86. Kyoung Kim H, Kyoung Kim Y, Song IH, Baek $\mathrm{SH}$, Lee SR, et al. Down-regulation of a forkhead transcription factor, FOXO3a, accelerate s cellular senescence in human dermal fibroblasts. $J$ Gerontol A Biol Sci Med Sci. 2005; 60(1):4-9. PMID: 15741276.

87. Li M, Chiu JF, Mossman BT, Fukagawa NK. Down-regulation of manganese-superoxide dismutase through phosphorylation of FOXO3a by Akt in explanted vascular smooth muscle cells from old rats. J Biol Chem. 2006; 281(52):40429-40439. PubMed: 17079231.

88. Miyauchi H, Minamino T, Tateno K, Kunieda T, Toko H, Komuro I. Akt negatively regulates the in vitro lifespan of human endothelial cells via a p53/p21-dependent pathway. EMBO J. 2004; 23(1):212-20. PMID: 14713953. 
89. Ferrara N, Rinaldi B, Corbi G, Conti V, Stiuso $\mathrm{P}$, Boccuti S, et al. Exercise training promotes SIRT1 activity in aged rats. Rejuvenation Res. 2008; 11(1):139-50. PMID: 18069916.

90. Haftmann C, Stittrich AB, Sgouroudis E, Matz M, Chang HD, et al. Lymphocyte signaling: regulation of FoxO transcription factors by microRNAs. Ann N Y Acad Sci. 2012; 1247:46-55. PMID:22236474.

91. Ouyang W, Beckett O, Flavell RA, Li MO. An essential role of the Forkhead-box transcription factor Foxo1 in control of T cellhomeostasis and tol erance. Immunity. 2009; 30(3):358-71. PMID: 19285438.

92. Venieratos PD, Drossopoulou GI, Kapodistria KD, Tsilibary EC, Kitsiou PV. High glucose induces suppression of insulin signalling and apoptosis via upregulation of endogenous IL1beta and suppressor of cytokine signalling-1 in mouse pancreatic beta cells. Cell Signal. 2010; 22(5):791-800. PMID: 20067833.

93. Peng C, Ma J, Gao X, Tian P, Li W, Zhang L. High glucose induced oxidative stress and apoptosis in cardiac microvascular endothelial cells are regulated by FoxO3a. PLoS One. 2013; 8(11). PMID: 24260294.

94. Bucur O, Ray S, Bucur MC, Almasan A (2006) APO2 ligand/tumor necrosis factor-related apoptosis-inducing ligand in prostate cancer therapy. Front Biosci 11: 1549-1568. PubMed: 16368536.

95. So CW, Cleary ML. Common mechanism for oncogenic activation of MLL by forkhead family proteins. Blood. 2003; 101(2):633-9. PMID: 12393557.

96. Ying Zhao, Yachen Wang, and Wei-Guo Zhu. Applications of post-translational modifications of FoxO family proteins in biological functions. $\mathrm{J} \mathrm{Mol}$ Cell Biol. 2011; 0:1-7. PMID: 21669942.

97. Paik JH, Kollipara R, Chu G, Ji H, Xiao Y, et al. FoxOs are lineage-restricted redundant tumor suppressors and regulate endothelial cell homeostasis. Cell. 2007; 128(2): 309-23. PMID: 17254969.

98. Yang XB, Zhao JJ, Huang CY, Wang QJ, Pan $\mathrm{K}$, Wang DD, et al. Decreased expression of the FOXO3a gene is associated with poor prognosis in primary gastric adenocarcinoma patients. PLoS One. 2013; 8(10):e78158. PMID:24194912.

99. Brenkman $A B$, van den Broek NJ, de Keizer PL, van Gent DC, Burgering BM. The DNA damage repair protein $\mathrm{Ku} 70$ interacts with FOXO4 to coordinate a conserved cellular stress response. FASEB J. 2010; 24(11):4271-80. PMID: 20570964.
100.Ausserlechner MJ, Salvador C, Deutschmann A, Bodner M, Viola G, et al. Therapy-resistant acute lymphoblastic leukemia (ALL) cells inactivate FOXO3 to escape apoptosis induction by TRAIL and Noxa. Oncotarget. 2013; 4(7):9951007. PMID:23828551.

101.Delpuech O, Griffiths B, East P, Essafi A, Lam EW, et al. Induction of Mxil-SR alpha by FOXO3a contributes to repression of Myc-dependent gene expression. Mol Cell Biol. 2007; 27(13):4917-30. PMID: 17452451.

102.Bucur O, Stancu AL, Goganau I, Petrescu SM, Pennarun B, et al. Combination of bortezomib and mitotic inhibitors down-modulate Bcr-Abl and efficiently eliminates tyrosine-kinase inhibitor sensitive and resistant Bcr-Abl-positive leukemic cells. PLoS One. 2013; 8(10):e77390. PMID: 24155950.

103.Ito Y, Daitoku H, Fukamizu A. Foxo1 increased pro-inflammatory gene expression by inducing $\mathrm{C} /$ EBPbeta in TNF-alpha-treated adipocytes. Biochem Biophys Res Commun. 2009; 378(2):290-5. PMID:19026986.

104. Su D, Coudriet GM, Hyun Kim D, Lu Y, Perdomo $\mathrm{G}$, et al, FoxO1 links insulin resistance to proinflammatory cytokine IL 1 beta production in macrophages. Diabetes. 2009; 58(11):2624-33. PMID:19651810.

105. Reed SA, Sandesara PB, Senf SM, Judge AR. Inhibition of FoxO transcriptional activity prevents muscle fiber atrophy during cachexia and induces hypertrophy. FASEB J. 2012; 26(3):987-1000. PMID: 22102632.

106. Mammucari C, Milan G, Romanello V, Masiero E, Rudolf R, et al. FoxO3 controls autophagy in skeletal muscle in vivo. Cell Metab. 2007; 6(6): 458-71. PMID: 18054315.

107.Zhao J, Brault JJ, Schild A, Cao P, Sandri M, et al. FoxO3 coordinately activates protein degradation by the autophagic/lysosomal and proteasomal pathways in atrophying muscle cells. Cell Metab. 2007; 6(6):472-83. PMID:18054316.

108. Chiacchiera F, Simone C. Inhibition of p38alpha unveils an AMPK-FoxO3A axis linking autophagy to cancer-specific metabolism. Autophagy. 2009; 5(7):1030-3. PMID: 19587525.

109.Tan WQ, Wang K, Lv DY, Li PF. Foxo3a inhibits cardiomyocyte hypertrophy through transactivating catalase. J Biol Chem. 2008; 283(44):29730-9. PMID:18772130.

110.Allen DL, Unterman TG. Regulation of myostatin expression and myoblast differentiation by FoxO and SMADtranscription factors. Am $J$ Physiol Cell Physiol. 2007; 292(1):C188-99. PMID:16885393. 
111.Altomonte J, Richter A, Harbaran S, Suriawinata J, Nakae J, et al. Inhibition of Foxo1 function is associated with improved fasting glycemia in diabet ic mice. Am J Physiol Endocrinol Metab. 2003; 285(4):E718-28. PMID:12783775.

112.Ni YG, Wang N, Cao DJ, Sachan N, Morris DJ, et al. FoxO transcription factors activate Akt and attenuate insulin signaling in heart by inhibiting protein phosphatases. Proc Natl Acad Sci $U S$ A. 2007; 104(51):20517-22. PMID: 18077353.

113.Kuningas M, Mägi R, Westendorp RG, Slagboom PE, Remm M, van Heemst D. Haplotypes in the human Foxo1a and Foxo3a genes; impact on disease and mortality at old age. Eur J Hum Genet. 2007; 15(3):294-301. PMID:17245409.

114.Furuyama T, Kitayama K, Shimoda Y, Ogawa M, Sone K, Yoshida-Araki K, Hisatsune H, et al. Abnormal angiogenesis in Foxo1 (Fkhr)-deficient mice. J Biol Chem. 2004; 279(33):34741-9. PMID: 15184386.

115.Sethi G, Shanmugam MK, Ramachandran L, Kumar AP, Tergaonkar V. Multifaceted link between cancer and inflammation. Biosci Rep. 2012; 32(1):1-15. PMID: 21981137.

116.Kim SY, Yoon J, Ko YS, Chang MS, Park JW, Lee $\mathrm{HE}$, et al. Constitutive phosphorylation of the FOXO1 transcription factor in gastric cancer cells correlates with microvessel area and the expressions of angiogenesis - related molecules. BMC Cancer. 2011; 11:264. PMID: 21696576.

117.Sengupta A, Molkentin JD, Paik JH, DePinho RA, Yutzey KE. FoxO transcription factors promote cardiomyocyte survival upon induction of oxidative stress. J Biol Chem. 2011 Mar 4;286(9):7468-78. PMID: 21159781.

118.Abid MR, Yano K, Guo S, Patel VI, Shrikhande G, et al. Forkhead transcription factors inhibit vascular smooth muscle cell proliferation and neointimal hyperplasia. J Biol Chem. 2005; 280(33):29864-73. PMID: 15961397.

119.Tsuchiya K, Westerterp M, Murphy AJ, Subramanian V, Ferrante AW Jr, et al. Expanded granulocyte/monocyte compartment in myeloid-specific triple FoxO knockout increases oxidative stress and accelerates atherosclerosis in mice. Circ Res. 2013; 112(7):992-1003. PMID: 23420833.

120.Watkins WJ, Umbers AJ, Woad KJ, Harris SE, Winship IM, et al. Mutational screening of FOXO3A and FOXO1A in women with premature ovarian failure. Fertil Steril. 2006; 86(5):1518-21. PMID: 16979636.

121. Yilmaz OH, Morrison SJ. The PI-3kinase pathway in hematopoietic stem cells and leukemia-initiating cells: a mechanistic difference between normal and cancer stem cells. Blood Cells Mol Dis. 2008; 41(1):73-6. PMID: 18387833.

122.Martínez DE. Mortality pattern suggest lack of senescence in hydra. Exp Gerontol. 1998; 33(3):217-25. PMID:9615920.

123.Eijkelenboom A, Burgering BM. FOXOs: signalling integrators for homeostasis maintenance. Nat Rev Mol Cell Biol. 2013; 14(2):83-97. PMID: 23325358.

124.Kwei KA, Baker JB, Pelham RJ. Modulators of sensitivity and resistance to inhibition of $\mathrm{PI} 3 \mathrm{~K}$ identified in a pharmacogenomic screen of the NCI60 human tumor cell line collection. PLoS One. 2012; 7(9):e46518. PMID:23029544.

125.Moghaddas Gholami A, Hahne H, Wu Z, Auer FJ, Meng C, et al. Global proteome analysis of the NCI-60 cell line panel. Cell Rep. 2013; 4(3):60920. PMID:23933261.

126.Wu C, Orozco C, Boyer J, Leglise M, Goodale J, et al. BioGPS: an extensible and customizable portal for querying and organizing gene annotation resources. Genome Biol. 2009; 10(11):R130. PMID:19919682.

127.Wu C, Macleod I, Su AI. BioGPS and MyGene.info: organizing online, gene-centric information. Nucleic Acids Res. 2013; 41(Database issue):D561-5 PMID:23175613.

128.Su AI, Wiltshire T, Batalov S, Lapp H, Ching $\mathrm{KA}$, et al. A gene atlas of the mouse and human protein-encoding transcriptomes. Proc Natl Acad Sci U S A. 2004; 101(16):6062-7. PMID: 15075390.

129. Wondisford AR, Xiong L, Chang E, Meng S, Meyers DJ, et al. Control of Foxo1 Gene Expression by Co-activator P300. J Biol Chem. 2014; 289(7):4326-33. PMID: 24379407.

130.van Roon EH, Boot A, Dihal AA, Ernst RF, van Wezel T, et al. BRAF mutation-specific promoter methylation of FOX genes in colorectal cancer. Clin Epigenetics. 2013; 5(1):2. PMID: 23324568.

131. Albulescu R, Neagu M, Albulescu L, Tanase C.Tissular and soluble miRNAs for diagnostic and therapy improvement in digestive tract cancers. Expert Rev Mol Diagn. 2011 Jan;11(1):101-20. doi: 10.1586/erm.10.106. PMID:21171925.

132.Neagu M, Constantin C, Tanase C. Immune-related biomarkers for diagnosis/prognosis and therapy monitoring of cutaneous melanoma. Expert Rev Mol Diagn. 2010; 10(7): 897-919. PMID: 20964610.

133.Kim KM, Park SJ, Jung SH, Kim EJ, Jogeswar $\mathrm{G}$, et al. miR-182 is a negative regulator of osteoblast proliferation, differentiation, and skeletogenesis through targeting FoxO1. J Bone Miner Res. 2012; 27(8):1669-79. PMID: 22431396. 
134.Guo Y, Liu H, Zhang H, Shang C, Song Y.miR-96 regulates FOXO1-mediated cell apoptosis in bladder cancer. Oncol Lett. 2012; 4(3):561-565. PMID: 23741253.

135.Lin H, Dai T, Xiong H, Zhao X, Chen X, et al. Unregulated miR-96 induces cell proliferation in human breast cancer by downregulating transcriptional factor FOXO3a. PLoS One. 2010; 5(12):e15797.

136.Xie L, Ushmorov A, Leithäuser F, Guan H, Steidl $\mathrm{C}$, et al. FOXO1 is a tumor suppressor in classical Hodgkin lymphoma. Blood. 2012; 119(15):350311. PMID: 22343918.

137.Wu Z, Sun H, Zeng W, He J, Mao X. Upregulation of MircoRNA-370 induces proliferation in human prostate cancer cells by downregulating the transcription factor FOXO1. PLoS One. 2012; 7(9):e45825. PMID: 23029264.

138. Wu C, Jin B, Chen L, Zhuo D, Zhang Z, et al. MiR- 30d induces apoptosis and is regulated by the Akt/FOXO pathway in renal cell carcinoma. Cell Signal. 2013; 25(5):1212-21. PMID: 23416459.

139. Singhal R, Bard JE, Nowak NJ, Buck MJ, Kandel ES. FOXO1 regulates expression of a microRNA cluster on $\mathrm{X}$ chromosome. Aging (Albany NY). 2013; 5(5):347-56. PMID: 23748164.

140.Brett JO, Renault VM, Rafalski VA, Webb AE, Brunet A. The microRNA cluster miR-106b 25 regulates adult neural stem/progenitor cell proliferation and neuronal differentiation. Aging (Albany NY). 2011; 3(2):108-24. PMID: 21386132.

DISCOVERIES is a peer-reviewed, open access, online, multidisciplinary and integrative journal, publishing high impact and innovative manuscripts from all areas related to MEDICINE, BIOLOGY and CHEMISTRY; (C) 2013, Applied Systems 